\title{
Güney Louisiana Kreole kültüründe inanışlar, kimlik ve bellek \\ Yonca DENIZZARSLANI
}

APA: Denizarslanı, Y. (2019). Güney Louisiana Kreole kültüründe inanışlar, kimlik ve bellek. RumeliDE Dil ve Edebiyat Araşturmaları Dergisi, (Ö6), 207-228. DOI: 10.2900o/rumelide.648852

$$
\ddot{\mathbf{O}} \mathbf{z}
$$

Güney Louisiana bölgesi, on beşinci yüzyıldan itibaren transatlantik sömürgeciliğin beşiği olan Karayipler'den aldığı Akdeniz, Afrika ve Latin Amerika kültürlerinin kavşak noktası olmuştur. Bölge, Fransız ve İspanyol sömürgeciliğinden miras Katolik-Kreole kültürüne özgü toplumsal tabakalaşması, yerel kimliğinde barındırmakta olduğu çeşitli inanışların ve ırkların melezliği ile günümüz Amerika Birleşik Devletleri’nin özel bir kültürel yöresidir. Güney Louisiana, 1803’ten itibaren Amerika Birleşik Devletleri sınırlarına dâhil edildikten sonra Anglo-Protestan Amerikan kimliğinin hâkimiyet alanına girmiştir. İç Savaş öncesi köleciliğe dayalı tarımsal üretimi, katı toplumsal sınıfları, seçkinci siyasi yapısı ve köleci toplumsal yapısının yarattığı ırk ayrımcılığı sebebiyle diğer Güney eyaletleri ile ortak özellikler taşımaktadır. Bununla birlikte, Güney Louisiana, önceki Fransız ve İspanyol sömürgeciliğine özgü Katolik-Kreole kültürel mirası ile günümüz Louisiana eyaleti sınırları içinde bile marjinal bir yerel kimlik olarak varlığını sürdürmektedir. Portekizce "yerli” anlamındaki criulo kelimesinden türetilmiş olan Kreole tanımı ilk olarak on altıncı yüzyılda Yeni Dünya'daki ikinci nesil Avrupalı sömürgeci yerleşimci nüfus için kullanılmıştır. Bu bağlamda, yeni sömürgeci nüfusun Avrupa'daki hanedan anakent kültürlerinden uzaklı̆̆ını ifade eden Kreole tanımı sömürgelerde gözlemlenen potansiyel siyasi bir tehdidin de temsili olmuştur. Daha sonraları Yeni Dünya sömürgelerinde başlayan transatlantik kölecilik ile birlikte Kreole tanımı, Afrika'dan Amerika'ya getirilen Afrikalı köleler ile Amerika'da doğan ikinci nesil köleler arasındaki hiyerarşiyi belirlemek için kullanmıştır. Zaman içinde Güney ve Orta Amerika’nın sömürgeci köleci toplum yapısının doğurduğu Avrupalı, Afrikalı ve Yerli Amerikalıların bir arada yaşam biçimi, Kreole tanımını hem ırksal hem kültürel bağlamda bir melezlik kavramına dönüştürmüştür. Böylece Kreole kavramı, günümüz Güney Louisiana'daki yerel inanışlar, kimlikler ve yerel bellek ile bütün, özgün bir kültürel öge olarak, bu yörenin, Amerika Birleşik Devletleri’nin ana akım siyasi erki ve toplumsal kimliğinin hâkimiyet alanına karşı direnç göstermesine olanak sağlamıştır. Bu çalışmada, Jewel Parker Rhodes'un Voodoo Dreams (1993) adlı romanı ve Mona Lisa Saloy'un Red Beans and Ricely Yours (2005) adlı şiir kitabında Güney Louisiana Kreole inanışları, kimlik algısı ve yerel bellek unsurları incelenecektir.

Anahtar kelimeler: Güney Louisiana, Kreole, Anglo-Amerikan, sömürgecilik, transatlantik kölecilik.

\section{Beliefs, identity and memory in Southern Louisiana Creole culture}

\begin{abstract}
Southern Louisiana has been a meeting point for Mediterranean, African and Latin American cultures, transferred from the Caribbean region, since the beginning of transatlantic colonialism by
\end{abstract}

Dr. Ö̆̆r. Üyesi, Ege Üniversitesi, Edebiyat Fakültesi, Amerikan Kültürü ve Edebiyatı Bölümü (İzmir, Türkiye), yonca.denizarslani@ege.edu.tr, ORCID ID: 00oo-0002-3762-9553 [Makale kaylt tarihi: 06.10.2019-kabul tarihi: 20.11.2019; DOI: 10.29000/rumelide.648852] 
the fifteenth century. As a reminiscence of the Catholic-Creole culture inherited from French and Spanish colonialism, its peculiar social stratification has shaped Southern Louisiana as a unique cultural region of the United States with its hybridized race codes and beliefs related to its local identity. Following its incorporation into U.S. borders in 1803 , the region came under the domain of Anglo-Protestant American identity. Thenceforth, Southern Louisiana shared similar socio-economic aspects with other regions of the American South, such as its agricultural economy based on slavery up to the Antebellum period, and its consequent offshoots of strict social stratification, oligarchic political traditions, and racism. Nevertheless, with its Catholic-Creole heritage of earlier French and Spanish colonialism, Southern Louisiana persists as a unique marginal local identity even in today's state of Louisiana. Stemming from its Portuguese root criulo, which means 'native,' the definition of Creole was initially used in the sixteenth century to identify the second-generation European colonial population in the New World. In this respect, with its inference of cultural distance and detachment between the colonies and their European metropoles, the definition of Creole was also inclusive of a rhetorical representation of a potential political threat. Later on, as an outcome of transatlantic slavery in New World colonies, the definition of Creole was used to identify the hierarchic category between the African slaves and the second-generation slaves born in the Americas. In due course, mixed social relations among the European, African and Native American colonial populations in Southern and Central America transformed the definition of Creole into a concept of racial and cultural hybridization. Thus, as an authentic cultural identity, today's concept of Creole has become a means for the revival and survival of the cultural alterities identified with contemporary Southern Louisiana, including local beliefs, identities and memories, as an alternative cultural space to the domain of main-stream Anglo-American identity and political power in the United States. This article focuses on Southern Louisiana Creole beliefs, identity and local memory with reference to Jewel Parker Rhodes's novel Voodoo Dreams (1993) and Mona Lisa Saloy's poems from her book Red Beans And Ricely Yours (2005).

Keywords: Southern Louisiana, Creole, Anglo-American, Colonialism, and transatlantic slavery.

\section{Giriş}

1980lerde Batı'da Sömürgecilik Sonrası edebiyat ile birlikte kültürel kimlik ve mekân ilişkisi üzerine yeni bakış açıları doğmuştur. Bir diğer yandan günümüzdeki toplu göçler ve küreselleşmenin getirdiği kültürel etkileşimler, ulus-devlet söyleminin yerleştirmiş olduğu kültürel, tarihi ve toplumsal hiyerarşilerin sorgulanmasını gerekli kılmıştır. Güney Louisiana'nın Kreole kültürü, bu bölgenin Fransız, İspanyol sömürgeciliği ve ABD tarihinden miras aldığı yerel dokusuyla günümüz hâkim ana akım Amerikan kültüründeki direnişini sürdürmektedir. Bugünkü Louisiana eyalet sınırlarından çok daha geniş olan Louisiana Bölgesi'nin 1803'te Fransa'dan Satın Alınması ile (“Louisiana Purchase”) ABD sınırlarına dâhil edilişinden sonra geçirdiği tarihi ve kültürel dönüşüm muazzamdır. İç Savaş öncesi Bölünme (“Antebellum”) (1846-61) ve sonrası Yeniden Yapılanma (“Reconstruction”) (1865-77) dönemlerinin yaratmış olduğu siyasi, ekonomik ve toplumsal çatışmalar Kuzey ve Güney eyaletleri arasındaki bölgesel farklılıkların daha da keskinleşmesine sebep olmuştur. Bununla birlikte, ABD, kuruluşundan bu yana Anglo-Protestan-Amerikan siyasi erkini ve bu mono-etnik kimliğini bölgesel farklılıkları gözetmeksizin adeta kadim bir üst-anlatı olarak günümüze dek sürdürmektedir. Fransız Louisiana Bölgesi'nin Satın Alınması'ndan sonra ağırlıklı olarak Katolik Fransız, İspanyol, Afrika ve Karayip kültürlerinin etkisinde olan Güney Louisiana'ya Kuzey eyaletlerden başlayan göç ile birlikte bu bölgedeki Fransız Kanadası kökenli Arkadiyen / Kajun (“Acadian / Cajun”) ve Avrupalı kreolelerin seçkinlerine rakip yeni bir Beyaz Anglo-Amerikan kimlikli toplumsal yapı hâkim olmuştur. Bu toplumsal 
dönüşüm, 1820lerde Güney Louisiana'da Fransız bir göçmen olan Charles Sealsfield'ın tutanaklarında ifade bulmuştur. Alexander Ritter, "Louisiana - the New Egypt: Charles Sealsfield's Report from the 1820s" adlı makalesinde, Sealsfield'ın bu gözlemlerini şöyle yorumlamıştır: "İdeolojik olarak bu monoetnik kimlikli yapı arayışı, Bağımsızlık Bildirgesi ilkeleri, 1789'daki ilk başkanlık seçimi ve ardından 'gelişmiş bir ulusal karakter ile özdeşleşme süreci' tarafından yönlendirilmiştir” (Ritter, 2008: 49). (Çeviriler bana aittir.) Böylece, günümüz Amerikan kültüründe halen baskın olan Anglo-Amerikan kimliğinin izlerini sürmek, Amerikan Güneyi üzerine de yerleşik hale gelmiş bu mono-etknik kimliğin baskısını anlamak açısından önemlidir. Amerikan demokrasisinin kuruluş aşamasında üretilmiş ve on dokuzuncu yüzyıl kıtasal yayılmacılık sürecinde hakimiyet alanı güçlenmiş olan bu Anglo-Amerikan kimlik söyleminde varolan ulusal ve bölgesel kimlik çatışmaları, esasen bu dönemde Kuzey Amerika'da eş zamanlı olarak mevcut bulunan diğer Avrupalı emperyal güçler ile ABD arasındaki iktidar çatışmalarının iç siyasete yansımasıdır. Bu bağlamda, Avrupa'da gelişen kültürel ve siyasi devrimlerin etkisi Yeni Dünya'da oluşmakta olan yeni ulus-devlet söylemlerinde de gözlemlenmektedir. ${ }^{2} \mathrm{Bu}$ karşıllklı etkileşimde, Yeni ve Eski Dünyalar iki farklı bilgi bilimi olarak birbiriyle buluşmuş ve zihinsel bağlamda bir çeşit melezleşme sürecine girmişlerdir. Bu süreç sadece siyasi anlamda değil din, dil ve toplumsal yaşam gibi kültürel bağlamda da kendini ortaya koymuştur. Örneğin, bölgenin var olan geçmiş Avrupalı sömürgecilik tarihine ek olarak, farklı Yerli Amerikalı kültürleri ile etkileşimler ve transatlantik köle ticareti, Güney Louisiana'nın günümüz çok kültürlü yapısının ortaya çıkmasında önemli bir rol oynamıştır. ABD’nin kuzeydoğu eyaletlerinin baskın Anglo-Amerikan kimliğine kıyasla, ABD’nin Güney bölgeleri mezhepsel, rrksal ve sınıfsal olarak çeşitli demografik özelliklerin yerleşik hale geldiği belli yerel kültür unsurlarına sahip farklı bölgelerden oluşmaktadır. Bölgenin tarihi dokusunda taşıdığı çok-kültürlülüğe atıf yapan Germain Bienvenu, bu unsurla bütünleşmiş olan Louisiana'nın diğer Amerikan Güneyi bölgelerine kıyasla demokrat bir karaktere sahip olduğunu ileri sürmüştür (Bienvenu, 2008: 25). Öte yandan, ABD’nin bu mono-etnik ulusal kimlik algısına meydan okuyan çok-kültürlü yapısının yanı sıra, Güney Louisiana'nın belli yerel özellikleri, bölgenin tarihini diri tutmuş ve yeni kültürel yapılarla kaynaşabilen esnek bir kimlik algısı yaratmıştır. Güney Louisiana'nın yerel belleğini muhafaza etmesini sağlayan öncelikli ve en önemli kültürel dürtüsü bölgenin Fransız ve İspanyol sömürgeciliği tarihidir. Öncelikle on yedinci yüzyllda Fransız sömürgesi olan Louisiana Bölgesi, on sekizinci yüzyllın sonuna doğru İspanya sömürgesi olarak el değiştirmiştir (1682-1762). Bölge 18011803 arasında kısa süreliğine tekrar Fransa'ya geri verilmiştir. Böylece, Güney Louisiana, 1803’ten itibaren ABD eyaleti olarak, İç Savaş öncesi Bölünme ve sonrası Yeniden Yapılanma dönemleriyle birlikte yaşanmış, etkisi günümüze dek sürmekte olan büyük toplumsal dönüşümlerin mekânı olmuştur. Başta Louisiana Eyaleti olmak üzere, Amerikan Güneyi köleci iş gücüne dayalı tarımsal ekonomisine tutunma ısrarı nedeniyle İç Savaş sonrasında Kuzeyin siyasal ve ekonomik düzeninin reformlarına tabi tutulmuştur. Köleciliğin kökenleri ve toplumsal sonuçları, bölgenin ayrımcı ırk, cinsiyet ve sınıf kodlarından oluşmuş olan çok-katmanlı kültürel yapılarında günümüze dek sürmüş olan uzun soluklu bir etki yaratmıştır. Bu süreçler acılı ve karanlık bir Sivil Haklar Hareketi mücadelesinin yanı sıra ABD'de halen var olma savaşımını sürdürmekte olan ötekileştirilmiş kimliklerin alanı haline gelmiş yeni kültürel mekânların ve melezliklerin doğmasına olanak tanımıştır. Böylece, Hem çatışma hem uzlaşma içinde yaşanmış kültür tarihi ile Güney Louisiana, zamansal ve uzamsal bağlamda oturmuş bir yerel kimlik ile özdeşleşmiştir. Günümüzde Yerli Amerikalı, Nova Scotia kökenli Arkadiyen/Kajun, Kreole, Kübalı, Haitili, Jamaikalı, Afrikalı Amerikalı ve Asyalı Amerikalı kültürel nüfusu ile müzikten yemeğe 
halk kültürü ve edebiyatı ile Güney Louisiana ana akım Amerikan kültürüne alternatif özgün bir yerel kültür mozaiği sunmaktadır.

Bu çalışma, Güney Louisiana Kreole kültürü ve edebiyatında yer etmiş olan yerel inanışlar, kimlik ve bellek unsurlarının bölgenin çok-kültürlü yaşantısının tarihsel süreçleriyle birlikte günümüz Amerikan kültüründeki yerinin incelendiği "Geçmişin İzinde Mesken Tutmak: Louisiana Kültüründeki Gelenek, İnanışlar ve Yerel Kimlik” adlı Bilimsel Araştırma Projesinin kapsamı içinde geliştirilmiştir. Bu bağlamda, Güney Louisiana'nın yerel inanışları, kimlik algısı ve bellek unsurları Jewel Parker Rhodes'un Voodoo Dreams (1993) adlı romanı ve Mona Lisa Saloy'un Red Beans And Ricely Yours (2005) adlı şiir kitabından örneklerle tartışılacaktır.

\section{Güney Louisiana Kreole kültüründe kimlik}

Berndt Ostendorf, Kreole tanımının, "kültür" sözcüğü ile köken olarak yakın anlam taşıyan "tarımsal üretim" manasını da içerdiğini ifade etmektedir. Tarımsal üretimde yetiştiricilik ve kültürleme süreçlerinin çağrıştırmakta olduğu gibi Amerikan sömürgecilik tarihinde Kreole tanımı da belli bir yapıdan farklı bir yapıya dönüşen sömürge kimlik yapısını, kişiliğini ve belli kültürel dönüşümleri vurgulamaktadır. Bu bağlamda Ostendorf'a göre sömürge ya da yeni kurulan ulus devlet söylemlerinde geliştirilmiş olan yeni çok-kültürlü oluşumlar için özellikle yemek isimlerinin kullanılması rastlantısal değildir. On dokuzuncu yüzyl ABD ulusal kimlik söylemi olarak baskın Beyaz Anglo-Protestan kimliğine asimilasyon için "eritme potası" ("melting pot”), çok-kültürlülük için "salata kasesi" ("salad bowl”) benzetmesi yapılması bu duruma örnektir (Ostendorf, 2008: 104-5). Sömürgecilik Sonrası eleştirel yaklaşımın anahtar kavramlarının bir araya getirildiği Post-Colonial Studies, The Key Concepts adlı sözlükte, İngilizce "Creole” teriminin, “yerli” anlamındaki Portekizce "Criolullu," İspanyolca "Criollo" ve yine "yerli halk" anlamındaki Fransızca "Créole" sözcüklerinden türediği ifade edilmiştir. Buna göre, Kreole tanımı ilk olarak tropikal bölgelerde doğmuş ve yetişmiş Avrupa kökenli beyaz nüfus için kullanılmıştır. Transatlantik köleciliğin başlamasıyla birlikte, yine bu bölgelerde doğan ve yetişen Avrupa kökenli olmayan ikinci nesil Afrikalı köle sömürge nüfusu için kullanılmıştır. Kreole terimi, Avrupalı ikinci nesil sömürgeci yerleşimcilerle melezleşmiş olan ikinci nesil Afrikalı ve Yerli Amerikalı nüfusların konuştukları dilleri tanımlayan bir tanım olarak da varlığını sürdürmüştür. Ancak İngilizcede daha yaygın anlamıyla on yedinci yüzyıllarda beyaz ve siyahî olarak Batı Antillerde doğmuş nüfusu tanımlamak için kullanılmıştır (Ashcroft, Griffiths, \& Tiffin, 2007: 50). Kreole kimliği özünde sömürgeci yerleşimci kimliklerde gözlemlenmiş kültürel bir bozulmaya işaret etmesi sebebiyle Avrupalı sömürgeci hanedan anakent iktidarlarına karşı siyasi bir tehdit olarak görülmüştür. Güney Louisiana Kreole kültürünün sömürgecilik tarihinden taşıdığı bu olgusal benzerlikle paralel olarak, Karen Ordahl Kupperman, Kreole kavramının, anakent merkezli baskın kimlik algısı açısından Yeni Dünya sömürgelerinin başkaldırı tehdidinin doğurduğu bir korkuyu temsil ettiğini ifade etmiştir (Bauer, Ralph \& José Antonio Mazzotti, 2009: 2). Böylece, Kreole tanımı, ilk olarak Portekiz, İspanyol ve Fransız sömürgecilik ve kölecilik tarihinin ana örgüsünde ortaya çıkmış, farklı kültür tarihlerinde yeni anlamlar kazanmaya devam etmiştir. Örneğin, günümüz Güney Louisiana kültüründe Kreole tanımı popüler şekliyle bu eski sömürgecilik ve kölecilik dönemlerinin ırk ve sınıf ayrımı kodlarından uzak, çok-kültürlü melez yemek, müzik ve edebiyat geleneklerini temsil etmektedir. Bununla birlikte, bu yeni Güney Louisiana Kreole kimliği, sömürgecilik ve kölecilik dönemlerinin anakent-sömürge hiyerarşisi bağlamındaki ayrımcı siyasi söylemleriyle benzer şekilde ana akım Amerikan kültüründe ötekileştirilmiş konumunu sürdürmektedir. Tıpkı eski beyaz Avrupa kökenli Kreole sömürgeci yerleşimcilerin hanedan anakentlerinden uzaklıkları sebebiyle kültürel ve ahlaki olarak bozulmuş kimlikler olarak temsil edildikleri gibi, günümüz Güney Louisiana Kreole kimliği kapsamındaki nüfus da, özellikle yaygın olarak 
Katolik inancının etkisinde olması, Akdeniz, Afrika ve Karayip kültürlerinin birleşimi çok-kültürlü melez yapısı sebebiyle Anglo-Amerikan merkezi erki için tehditkâr ve dışlanmış bir konumdadır. Bu kültürel çatışma, 2005'te New Orleans şehrini yok eden Katrina Kasırgası sonrası Federal Hükümetin bölgeye neredeyse hiç ilgi göstermemesiyle en belirgin şekilde anlaşılmıştır. Bu bağlamda, Güney Louisiana Kreole kültürünün bu kadim Yeni Dünya iktidar-özne çatışma dönemlerinde temsil bulduğu farklı kimlik algılarına kısaca bakmak gerekmektedir. Berndt Ostendorf, Louisiana Bölgesinin on dokuzuncu yüzyılda ABD’ye dâhil olmasından sonra bölgede mevcut olan Fransız ve İspanyol Kreole seçkinlerinin yerel kimlik aidiyetinin, yeni başlayan Anglo-Amerikan göç akımı ile birlikte eskisinden daha duyarlı şekilde sahiplenildiğini vurgulamaktadır. Richard A. Long da bu yeni dönemde Kreole kimliğinin, Avrupalı Kreole nüfus ile melezleşmiş ikinci nesil özgür veya köle Afrikalı nüfus yerine sadece Avrupa kökenli Kreole nüfusu diğer yeni Anglo-Amerikan nüfustan ayırmak için kullanılmasını, bu yeni ideolojik kimlik çatışmasına bir örnek olarak vermektedir (Ostendorf, 2008: 108). Bu yüzden, on dokuzuncu yüzyıl itibariyle, ABD hâkimiyeti altında, bu hiyerarşik üstün Kreole nüfusunu bölgedeki diğer Afrika kökenli Kreole nüfustan ayırt etmek için yeni Afrika kökenli Kreole tanımları ortaya çıkmıştır. Böylece, ABD Louisiana eyaletinde doğmakta olan köle veya özgür Afrika kökenli Kreole için "Kreole Zenci" ("Creole Negro") tanımı kullanılırken, Avrupa kökenli Kreole nüfusla melezleşmiş nüfusa "kırma" ("Half breed”) tanımı getirilmiştir (Ostendorf, 2008: 107). Özetle, Güney Louisiana'da Kreole kimliği on dokuzuncu yüzyıl boyunca yaygın şekilde ırksal köken ayrımlarını belirleyen bir tanım olarak kullanılmıştır. Ostendorf, Avrupa kökenli Kreole tanımının ise farklı bir hiyerarşiye çekildiğini ve bu tanım içindeki "saf kan" Avrupalı Kreole unsurunun, Güney Louisiana'daki Katolik Kreole nüfusa söylencesel bir anlam kattığını ifade etmiştir.3 Yine bu nüfusu siyahî Kreole nüfustan ayırmak için "ilkel" ("sauvage”), "sömürge” (“esclave”), "zenci kadın" (“negresse”), "melez kadın” ("mulatress"), "zenci” ("negrion”) ve "özgür zenci” ("nègre libre") gibi tanımlar kullanılmıştır. (Ostendorf, 2008: 109) Öte yandan, Güney Louisiana'nın ABD dönemi dahil olmak üzere sömürgecilik dönemlerinden itibaren geçirdiği demografik hareketlilik ve toplumsal değişim, "saf kan” Fransız kökenli Kreole gibi özel bir tanımın esnemesine yol açmıştır.

$\mathrm{Bu}$ çalışma kapsamında incelenmekte olan Afrika kökenli Kreole kültürünün Güney Louisiana kültür tarihinde yaygın olarak Katolik inancıyla melezleşmiş belli Afrika ve Karayip kökenli inanışlar, kimlik ve bellek algısıyla dönüşüme uğradığı görülmektedir. Fransız ve İspanyol hâkimiyeti döneminde Louisiana'da kısa sürede artan köle nüfusunu beyaz Kreolelerin hiyerarşik üstünlüğü açısından denetim altına alma gerekliliği 1724 Siyah Yasasını (“Code Noir”) getirmiştir. Toplumsal yaşantıda beyazlar ile özgür veya köle olan siyahî nüfus arasındaki ayrım bağlamında kamusal alan kurallarının belirlendiği Siyah Yasası, ABD hâkimiyet döneminde İç Savaş sonrası köleciliğin kaldırılmasına rağmen bu ırk ayrımcılığının meşruiyetini korumak için Jim Crow Yasasına dönüştürülmüştür. Bununla birlikte, ırk ayrımcılığı bağlamında ABD tarihinde sürekli bir çatışma alanı olarak devam eden Sivil Haklar Hareketi mücadele sürecinde Siyah Yasası veya Jim Crow Yasası gibi uygulamaların bir yandan beyaz ve siyahî kültürlerin farklı bilgi bilimleri ve materyal kültürlerini kaçınılmaz olarak bir araya getiren yeni melezlik olgularını doğurduğu görülmüştür. Bu olgulardan en etkili olanı bölgenin Katolik inancı ve AfrikaKarayip kökenli yerel inanışları olarak gözlemlenmektedir. Fransız dönemi Siyah Yasası sömürgedeki Afrikalı kölelerin Katolik inancına döndürülmelerini ve vaftiz edilmelerini gerekli kılmıştır. Bu kurala göre köleler sömürgedeki tüm Katolik nüfusla birlikte kutsal günlerde ve Pazar günleri sinırlı ölçülerde olsa da özgür bırakılmıştır. Bu baskıcı uygulama ironik bir şekilde kölelerin Afrika ve Karayiplerden getirdikleri kültürleri ve kendi inanışlarına özgü ayinlerini yapabilme olanağı sağlamıştır. Örneğin, New

3 On altıncı ve on dokuzuncu yüzyıllar arasında ırk özellikleri ve ayrımlarının kan ile tanımlaması hakkında bakınız: Kimberly Anne Coles, Ralph Bauer, Zita Nunes, Carla L. Peterson (eds.) (2014). The Cultural Politics of Blood, 1500-19oo. Palgrave Macmillan. 
Orleans’taki Kongo Meydanı Afrikalı kölelerin inanışlarıyla özgünleşmiş dans ve müzik kültürlerini yaşattıkları önemli bir mekân olmuştur. Böylece, Pazar günleri sosyalleşme imkânı bulan kölelerin BatıAfrika'nın farklı kavimlerinden ve Karayiplerden getirdikleri çeşitli materyal kültürlerini yaşattıkları Kongo Meydanı Güney Louisiana'nın kültür tarihini günümüze taşıyan sembolik bir mekâna dönüşmüştür. Günümüzde de her yll New Orleans'ta düzenlenmekte olan Mardi Gra karnavalı Kongo Meydanı kutlamalarından miras alınan Afrika kökenli müzik ve dans eşliğindeki şenlik yürüyüşleriyle ünlüdür.

\section{Güney Louisiana'da Katoliklik ve Afrika-Karayip kökenli inanışlar}

Marcia Gaudet, "Cultural Catholicism in Cajun-Creole Louisiana" adlı makalesinde günümüz Güney Louisiana Katolik-Kreole inanışlarını bir çeşit "kültürel Katoliklik" olarak ifade etmektedir. Gaudet, yirminci yüzyıla kadar Roma Kilisesinin Kuzey Amerika'daki misyonerlik faaliyetlerinin zayıflamış olması ve yetkili kilise görevlilerinin özellikle Kajun-Kreole gibi izole etnik nüfusun yaşadığı uç taşra bölgelerine neredeyse hiç ulaşmamış olmasından dolayı bu bölgede çeşitli halk inanışlarıyla bütünleşmiş farklı bir Katolik inancının ortaya çıtığını eklemektedir. Kreole nüfusun etkilendiği Katoliklik kökenli inanışlara bir örnek, şifa verdiğine inandıkları bir takım azizler grubuna yönelik ibadet etmeleridir. Böylece Gaudet'e göre, İsa Mesih'in çarmığa gerilmesini sembolize eden kutsal çarmıh, Katolik-Kreole kültüründe büyü amaçlı bir dini inanışa dönüşmüştür. Bu inanışa göre kutsal çarmıh, insanları fırtına ve kasırgalardan koruyan büyülü bir güce sahiptir. Kanon olarak belirlenmiş Roma Kilisesi inanç ilkelerinde böyle bir kutsal çarmı kavramı bulunmamaktadır. Gaudet, Güney Louisiana kültürel Katolikliğinde dönüşüme uğramış olan kutsal kavramına, Patricia Rickels'in "The Folklore of Sacraments and Sacramentals in South Louisiana” adlı makalesinden örnek vermiştir. Rickels, Katolik inancındaki bu halk kültürü ögelerini ve kutsal kavramının önemini tartışmaktadır. Kilise otoritesinin dışında gelişmiş olan halk inanışlarında kutsalların yeri merkezidir. Belli günler, kilise ayinleri ve dekorasyon figürlerinden oluşan bu kutsallar arasında kutsal çarmı sembolü, kutsal su, kutsanmış yağ, mumlar, palmiye yaprakları, küller, merasim elbisesi, madalyon, çarmıh, tesbih ve duaları sayabiliriz. Rickels, tüm bu kutsalların halk inanışında büyücülük amaçlı bir din anlayışı ("magico-religous purposes”) yarattığını ifade etmektedir. Oysa Katolik Kilisesinin bu kutsalları meşru kılmasının tek amacı sadece Tanrının hoşnutluğunu kazanmak ve ibadeti teşvik etmektir. Rickels bu kutsallara örnek olarak, kötü ruhlardan korunmak için gece yatmadan önce yatağın etrafına ve kasırga ikliminde korunmak için evin etrafına kutsal su serpme âdetinden söz etmektedir. Aynı şekilde evdeki hastaların iyileşmesi için kutsanmış mum yakılması da bu inanışlar arasındadır. Folklorist David Hufford'a göre resmi din öğretileri ve bu tip yarı-resmi kültürel Katoliklik inanışlarının arasında karmaşık bir ilişki bulunmaktadır. Kilise tarafından resmen meşru görülmüş olmasa da bu tip inanışlar, Güney Louisiana'da yaygın bir kültürel geleneğin temel unsuru olmuştur. Hufford'a göre bu inanışlar grup aidiyetini sağlamanın yanı sıra resmi dinin soyut teolojisini daha somut bir gerçekliğe dönüştürme ihtiyacının kültürel yaşamdaki yansıması olmuştur. Amanda Banks'ın da ifadesiyle, böylece resmi dinin dogmatik yapısı kültürel ve toplumsal yaşamın gündelik işlerine ve ihtiyaçlarına karşıllk verir hale getirilmiştir (Folk Life in Louisiana). Sonuç olarak, kültürel Katolikliğin Güney Louisiana kimliklerine aidiyet duygusu ve yerellik özelliği getirdiği anlaşılmaktadır. Louisiana Bölgesi'nin 1803’te ABD topraklarına dâhil olmasıyla bölgedeki Kreole kimliğinin daha önceki Fransız ve İspanyol sömürge dönemlerinde hiç görülmediği kadar ön plana çıkması gibi, kültürel Katolikliğin de yeni gelen AngloProtestan göçle başlayan asimilasyon sürecine karşı liminal bir alan olarak varlığını sürdürdüğü açıktır.

Güney Louisiana'daki diğer inanışlar arasında Afrika-Karayip kökenli olanlar görülmektedir. Afrika'dan getirilen kölelerin putperest inanışları, köle sahiplerinin Siyah Yasası gereği kölelerini zorunlu olarak 
vaftiz etmesiyle Katoliklik inancı ile melezleşmeye maruz kalmıştır. Afrika kökenli inanışların New Orleans şehir tarihinde yerleşik hale gelmesi kutsal günler ve Pazar günlerinde kölelere serbest bırakılan Kongo Meydanı şenlikleriyle başlamıştır. Freddi Williams Evans'in Congo Square African Roots in New Orleans (2011) adlı çalışması, Kongo Meydanı ayinlerinden doğan Afrika kökenli müzik ve dans kültürünü incelemektedir. Evans, Kongo Meydanının, köle nüfusa sadece inanış özgürlüğü sunmakla kalmadığını, kendilerine ayrılmış bu özgür alanda birbiriyle ticari ve kültürel etkileşim kurabilme imkânı verdiğini ifade etmektedir. Böylece günümüz New Orleans Afrikalı Amerikalı nüfusu için Kongo Meydanı sadece bir lokasyon değil, şehrin sömürge tarihinde gömülü köklü bir geçmişin sembolüdür. New Orleans ile özdeşleşmiş bir diğer Afrika kökenli inanış Voodoo ayinleridir. Bu inanışla birlikte New Orleans Voodoo kültü, Robert Tallant'ın Voodoo in New Orleans (1946) adlı kitabıyla ünlü olmuştur. Tallant, Voodoo kraliçesi Marie Laveau başta olmak üzere New Orleans'ta bilinen ünlü büyücüleri, şifacıları ve ayinlerini betimlemiştir. Tallant, kitabının ilk bölümünde New Orleans'ın Katolik-Kreole karakteriyle özdeşleşmiş Voodoo inanışı ile birlikte caz müziği, yemek kültürü ve toplumsal sınıfları da resmetmiştir: "Bazen New Orleans'ta bir beyaz adam Amerika'nın en işlek Zenci caddelerinden biri olan Güney Rampart Caddesinde yürüyüşe çıkar. Şehrin en önemli iş merkezi olan Kanal Caddesine döner ve kendisini özel mekânları, sesleri ve kokularıyla yeni bir dünyada bulur" (Tallant, 2012: 3). Tallant, New Orleans'ın siyahî mahallelerinde gezinen hayali beyaz adamın bu mekâna aidiyetsizliğini ve yabancılığını vurgulamaktadır. Güney Rampart Caddesi ve Kanal Caddelerinin kendilerine özgü ses, koku ve görüntüleri, bu beyaz adama öncelikle ait olmadı̆̆ı farklı bir dünyada bulunduğunu hissettirir. İlerleyen bölümlerde bu gezgin beyaz adamın Rampart Caddesinde duyumsadığı gerçeklik biraz daha detaylandırılmaktadır: “... Bayat bira ve viski, kavurucu sıcağın altındaki istiridye varilleri, açık pencerelerden gelen mangalda soğanlı hamburger, ter ve ucuz parfümün aromalı karışımı ve bazı kapı aralıklarında gezinen meraklı tütsü kokusu” (2012: 4). Rampart Caddesine bir iş sebebiyle gelmemişse, beyaz adamın fark edeceği ilk şey buranın yabancısı olduğu gerçeğidir. Hatta beyaz mahallesinde gezinen bir siyahın da kendisi gibi yabancı hissedeceğini düşünür. Bu beyaz adam ayrıca siyahların beyazları, beyazların siyahları tanıdığından çok daha iyi tanıdığını da düşünür. Rampart Caddesinde yürürken siyahların kendilerine özgü gizemli bir dünya yaratmış olduklarını hisseder. Bu gizemli dünya kendine özgü korunmuş ambiyansına rağmen beyaz adamın ayak basmasıyla anında geçmişin irksal kodlamalarla yerleşik hale gelen reflekslerine dönebilecek kadar da hassastır:

\begin{abstract}
Beyaz adam burada kendisinin davetsiz misafir olduğunu hisseder, ancak banket üzerinde bir grup Zenciye rastladığında - banket, ülkenin başka yerlerinde "kaldırım" kelimesi için kullanılan New Orleans'a ait bir kelimedir - Zenciler kenara çekilir ona yol verir. Nesiller boyu beyaz adam için yol vermek otomatik tepkiye dönüşmektedir. Yüzlerinde nefret yoktur. Ne de tevazu. Belki nereye gittiğine ve bu muhitte ne aradığına dair biraz merak vardır. (2012: 4)
\end{abstract}

Tallant, New Orleans'ın siyahî muhitlerinde gezinen bu hayali beyaz adam imgesiyle irk ve toplumsal sınıf gibi sınırların tarihi hiyerarşik yapısını çözen bir kültürel algıyı da ortaya koymaktadır. Beyaz adamın isimsiz olması kolektif bir kültürel deneyimin yansıtılması açısından semboliktir. Bununla birlikte, sesler, kokular, sokaktaki insanların jestleri bu beyaz adamın algllayabildiği bir gerçeklik iken yolda ilerlerken algılanabilmesi imkânsız bir başka dünya ile de karşılaşır. Muhitin daha kenar bölgelerine doğru ilerlediğinde kaldırım üstünde belli köşe başlarında çeşitli otlar, mum ve tütsü satıcıları ve genellikle tuhaf görünümlü olan yaşlı kadın müşterileri fark edecektir. Tallant, semtin bu noktadan sonraki dünyasının beyaz adama kapalı olduğunu ifade etmektedir. Satıcılara müşteri gibi yaklaşsa da kimse onunla iletişim kurmak istemeyecektir, çünkü Voodoo otoritenin kabul etmediği bir alandır. Bu yüzden büyük olasılıkla polis olduğunu düşüneceklerdir: "Burada bir bariyer ile karşlaşmıştır. (Bu noktanın) Ötesinde Güney Rampart Caddesi dünyasının büyücülüğünün yer etmiş olduğu sınırı geçemez. Herkes ona kibar davranacaktır ancak - tanınmış bir beyaz Voodoo değilse, ona 
hiçbir şey söylemeyeceklerdir” (2012: 4). Beyaz adam istediği kadar bu civarda gezinebilir ama Güney Rampart Caddesindeki bu gizemli dünyaya dair soru soramaz. Tallant'in bu muhitin gizemine dair eklediği bir detay daha vardır. Satıcıların çoğu kanının dörtte birinin siyah ırktan olduğuna inanılan quadroon adlı melez kimliktendir. New Orleans'ta çoğunluğu oluşturan bu quadroon nüfus, sadece demografik nicelik açısından değil ama aynı zamanda kanında barındırdığı düşünülen beyaz ırk kanı miktarının fazla olması nedeniyle tam bir sınır kimliktir. Bu dönemdeki ırk tanımlamaları yaygın şekilde kan üzerinden yapılmaktadır. Bu bağlamda quadroon kimlik, New Orleans'ta irk sinırlarının en acımasız şekilde çizildiği bir tarih ve coğrafyada belirsiz olanı temsil etmektedir. Ürkütücüdür. Bir şey satın almak isteyip istemediğini soran quadroon satıcı figürü ile ürperen beyaz adam derhal oradan ayrlmak isteyecektir:

\begin{abstract}
'Bayım bir şey satın almak istiyor musunuz?' Beyaz adam kafasını çevirip baktığında bazen quadroon'larda olduğu gibi açık kahve renk derisi ve duman-grisi gözleri olan genç adamın yüzüne bakacaktır. Ve beyaz adam bazı olumsuz sözler mırıldanacaktır ve arkasına bakmadan, neredeyse Caddeden çok uzaklara, kendi beyaz Dünyasına varana dek yürüyecektir. Sanki metafizik bir güç onu ait olmadığı mekânın dışına savurmuştur. (1946:4)
\end{abstract}

Tallant Voodoo in New Orleans kitabına bu kurgusal beyaz adam figürü ile başlar. Yazar'ın Voodoo'nun Fransız ve İspanyol Louisiana'sı ve 1803 sonrası Amerikan Louisiana'sı dönemlerinde geçirdiği tarihsel dönüşümü vermeden önce okuyucuya Voodoo'nun Güney Louisiana'nın rrk ve kimlik tanımlamalarındaki bu çatışmaların çözüldüğü özgün bir kültürel temsil olduğunu ifade etmesi önemlidir. Güney Louisiana tarihi boyunca siyahî ırkın maruz kaldığı siyasi tanımlamalara ve ırk ayrımcılığına şifa olmamıştır Voodoo. Öte yandan tüm bu çatışmaların varlığına alternatif bir direniş potansiyelinin sembolü olmuştur. Ayinlerinde Katolik inancının kutsalları olan kutsal çarmıh, kutsal su ve mum gibi sembolleri barındırması bakımından Voodoo resmî dinin gözünde hem yasadışıdır hem de Katolikliğin temel inanç ilkelerini bozan putperestliği yaygınlaştırmış olması bakımından önemli bir tehdittir. Geçmişte Kongo Meydanı ayinleri ve New Orleans'ın bu kenar mahallerine büyü yaptırmak için akın edenler sadece çaresiz köleler değil aynı zamanda beyaz Kreole nüfustur. Böylece, Marcia Gaudet’in ifade ettiği kültürel Katoliklik ile Afrika ve Karayip kökenli Voodoo inancının Güney Louisiana'daki etkisini, bölgenin sömürgecilik tarihinden günümüze ana akım Amerikan kültürünün hiyerarşik üstün iktidar düzeni ile özneleri arasında liminal bir alan olarak düşünebiliriz.

\title{
4. Jewel Parker Rhodes'un Voodoo Dreams (1993) Adlı Romanı ve Mona Lisa Saloy'un Red Beans And Ricely Yours (2005) Adlı Şiir Kitabında Kreole İnanışlar, Kimlik ve Bellek
}

Görüldüğü gibi, Güney Louisiana'da ırksal çatışmaların da bir alanı olan inanışlar, Afrikalı Amerikalılar için yüzylllar süren kimlik mücadelesinde kendi özgün kültürlerine meşruiyet kazandırmada önemli bir araç olmuştur. Bu bölümde, Güney Louisiana'da Katolik inancı ile melezleşmiş Afrika ve Karayip kökenli inanışların bölgenin mevcut ırksal çatışmalarındaki temsili ve yerel belleğindeki önemi incelenecektir. Jewel Parker Rhodes, Vodoo Dreams (1993) adlı romanı ile New Orleans'ın ünlü on dokuzuncu yüzyıl Voodoo Kraliçesi Marie Laveau'nun hayatını kurgulaştırmıştır. Marie Laveau 1819'da on altı yaşında, büyükannesiyle büyüdüğü Mississippi’nin Teché adlı bataklık kolundan New Orleans'a geldiği ilk gün kendisine ömür boyu büyük hayranlı duyacak olan yarı Anglo-Amerikan yarı Fransız Kreolesi Louis DeLavier ile tanışır. Romanda Louis DeLavier’in günlüklerinden derlenmiş olan kurgu, böylece aynı zamanda Marie Laveau'nun büyüme öyküsüdür. Eski Voodoo kraliçesi olan büyükanne ve annesiyle birlikte Marie Laveau, bu geleneğin üçüncü kuşak temsilcisidir. Kızının ölümüne sebep olan bu aile geleneğine son vererek Katolikliğe geçen büyükanne, torunu Marie’den bu geçmişi saklamak ister. 
Torunu on altı yaşına gelene kadar Teché ırmak boyunda vahşi doğanın içinde insanlardan uzakta yaşarlar. Büyükannesinin Voodoo geçmişini bilmeyen Marie'nin sezgileri ise Katoliklikle kendi kültürleri arasında bir uyumsuzluk olduğu yönündedir. Marie'nin bu yöndeki sezilerini güçlendiren bir olay önemlidir. Marie ve büyükannesi New Orleans'a geldikleri ilk gün Fransız Kreolesi Antoine DeLavier’in zulmüne maruz kalır. Marie ve büyükannesinin at arabası, içinde Louis DeLavier ve nişanlısı Brigette DeLavier'in de bulunduğu Antoine DeLavier’in at arabasıyla çarpışır. Brigette'in yaralanmasına sebep olan kazadan sonra Antoine DeLavier, Marie ve büyükannesinin "özgür siyahîlerden" ("free people of color") olduklarına inanmaz ve o dönemin acımasız Siyah Yasasını ("Black Code”) uygulamak ister. Kaçak köle olduklarını ve efendileri sahip çıkana kadar ikisini de esir tutacağını söyleyerek büyükanne ve torununu tehdit eder. On altı yaşına dek Teché ırmak boyunda Louisiana'nın tüm irk ve sınıf kodlarından izole edilmiş şekilde büyümüş olan Marie Laveau, Antoine DeLavier'a saldırınca iş çı̆̆ırından çıkar. O sırada oradan geçen Santo Domingo'lu quadroon denizci Jacques Paris, -Antoine DeLavier'in deyimiyle "melez piçi” (“A bastard quadroon”)- olaya karışır, Marie'nin kız kardeşi olduğunu, şehre yeni geldiklerini ve kuralları bilmediklerini söyleyerek büyükanne ile torununu korumak ister. Bu müdahale ile öfkesi kontrolden çlkan Antione DeLavier, Jacques’i ölesiye dövmeye, kırbaçlamaya başlar. Siyah Yasası gereği Jacques, Antoine DeLavier’a karşı pasif kalmak zorundadır. Beyaz adama saldırmanın cezası her ne koşulda olursa olsun idamdır. Tek yapabildiği Antoine DeLavier'ı düelloya davet etmektir. Bu davet Antoine DeLavier açısından bir aşağılanma olduğu için geri çevrilir. Denizci kırbaç darbeleriyle neredeyse ölmek üzereyken büyükanne eski tanrılarından Guédéyi çağırmaya başlar. Bu olay üzerine, Katolik olmasına rağmen büyükannesinin çağrısı, Marie'nin annesi ve büyükannesinin geçmişiyle ilgili bilmediklerine karşı merakını artıracaktır:

\begin{abstract}
Büyükanne derin nefes aldı. Ağzından ciğerlerine güçlü nefes aldı. Boğazının ardında bir hımlama gürledi. "Guédé, Guédé, Guédé... gel ve duamı duy... Guéde, Guédé, Guéde... hizmetkarının sana ihtiyacı var....” Büyükanne ölmüş tanrıları görmek için tüm dikkatini topladı. Onun görme gücü tanrıları gerçek kılardı.
\end{abstract}

$\cdots$

Büyükanne ayakta kollarını uzatmış duruyordu. Rüzgâr Körfezden meydana doğru esmeyi bıraktı... Büyükanne, davetiyle hoşnut olmuş kadim ruhların yakınlarda süzüldüğünü hissedebiliyordu. Bunca yıl sonra ne kadar çabuk yanıt verdiklerini görünce şaşırdı. İçi özgüven ile doldu.

Guédé, ahenk içinde "Yap," dedi "Yap artık."

"Yapamam. Yapamam.” Büyükanne yığıldı kaldı. Günahı savuşturarak, “Öldürmeyeceksin. Öldürmeyeceksin.” diye mırıldanarak, tesbihini gözlerine bastırdı.

Boğuk sesle, Marie’ye, "Büyüler. Onları kullanmıyorum. Bir insanı öldürmek ruha çok ağır” dedi (Rhodes, 1995: 48-9).

İstediği an Antoine DeLavier’i büyü ile öldürebilecek güce sahip olan büyükanne Katoliklikte büyü ile insan öldürmenin büyük bir günah olduğunu hatırlar ve vazgeçer. Büyükanneyi büyü yapmaktan vazgeçiren Katolik inancının etkisi roman boyunca sıklıkla görülmektedir. Her ne kadar Afrika kökenli inanışlarıyla uyumsuz olsa da Katolikliğin siyahîler üzerinde etkisinin büyük olduğu anlaşılmaktadır. Bölgenin tarihinde Katolikliğin Afrikalı nüfus üzerindeki etkisi sadece melezleşmiş inanışlar bağlamında değil, köleci toplumun belirlediği hiyerarşileri ve statüleri meşrulaştırmada da bir araç olduğu anlaşılmaktadır. Marie ve büyükannesi New Orleans’a giderken yol üzerinde pamuk tarlalarında çalışan kölelerin Ürdün Nehri ilahisini mırıldandıklarını duyarlar:

Naif bir ruh içinde, Marie en çok tarlada çalışan insanların manzarasından hoşlandı. Pamuk dizilerinin ve renksiz beyazlığı toplayan siyah ellerin simetrisini sevdi. Özellikle işçilerin seslerini 
yükselterek söylediği melankolik şarkıyı sevdi. Büyükannesinin sesinin yüzlercesiyle yankılanması gibiydi.

Marie sorsaydı, Büyükanne ona işçilerin yorgun olduğunu ve tatlı "Ürdün Nehri” ilahisinin Afrika'daki özgürlüğe duyulan hasreti ve öteki dünyadaki huzuru ifade ettiğini söylerdi. (1995: 42-3)

Büyükannesinden aldığı eğitime rağmen Marie'nin Katoliklikle ilgili huzursuzluğuna bir başka örnek, Marie'nin kendisini Antoine DeLavier'in elinden kurtaran kahramanı quadroon denizci Jacques ile evlendiği katedralin iç mekân betimlemeleridir:

Katedralden içeri girerken semboller ve azizlerin kalıntılarıyla aşağılanmış hissetti. Düzinelerce inci işlemeli altın çarmı duvarlarda asılıydı. Kutsal su kâseleri girişlerdeki sütunlarına yerleștirilmiş ve her köşede buhur yakılmaktaydı. Vaftizci Yahya'nın, Aziz Petrus'un, Bakirenin ve İsa Mesih'in gerçek boyutunda heykellerinin önünde yüzlerce mum titreşiyordu. Komünyon İkramının hazırlandığı, altın, yakut ve pırlantalarla süslenmiș devasa mermerden mihraba giden yol ve oturaklar kadife ile kaplıydı. Atmosfer dingin, hürmetkârdı ve Marie Katolik kilisesinin ihtişamıla zenginliğini yoğun şekilde hissediyordu. (1995: 107)

Katedralin dekorasyonundaki süslemeler, mihrap üzerindeki semboller, göz alıcı altın ve inci kaplamalı haçlar, tüm bu imgelem yığını ile çevrelenmiş olan Marie kendini aşağılanmış hisseder. Kilisenin iç mekânı Katolik kilisesinin otoritesi ve zenginliğini temsil etmektedir. Katedraldeki bu dekoratif süslemeler, İsa Mesih’i sergileyen kanlı kutsal çarmıllar ve mihrap üzerindeki semboller, aslında bir yandan putperest ayinleriyle de bir benzerlik sergilemektedir. Bu unsurların, Katolikliğin kölelerin Afrika kökenli inanışlarıyla melezleşmesine olanak sağlamak bakımından etkili olduğu anlaşılmaktadır. Bu ortaklığa bir diğer örnek de romandaki Christophe Baba karakteridir. Yaşayan bir aziz gibi saylan Christophe Baba New Orleans'ta binlerce humma hastasını iyileştirmekle birlikte bir kere bile bu hastalığa yakalanmamıştır. Marcia Gaudet, "Traiteur” olarak bilinen bu şifacıllk geleneğinin günümüz Güney Louisiana'da halen önemli bir geçim kaynağı olduğunu ifade etmektedir (Folk Life in Louisiana). Federal devletten destek görmeyen Louisiana Eyaleti'nin eğitim ve sağlık hizmetlerinin en düşük bölgelerden olduğu düşünüldüğünde bölgenin yerel kültüründe yerleşik hale gelmiş olan bu inanışların etkinliğini anlaşlır bir toplumsal olgudur.

Geleceğin Voodoo kraliçesi olmaya yazgılı olan Marie'nin evlilik ayini esnasında geçirdiği iç çatışmalar, romanda Katoliklik ile Afrika kökenli inanışların melezliğinin temsili bağlamında karakterin edilgen öteki konumundan özne konumuna geçiş sürecini betimlemesi açısından önemlidir:

\begin{abstract}
Marie mihrabın önünde diz çöktüğünde bir İsa heykeli yukardan ona baktı. Ellerine ve Ayaklarına çivi çakılan yerleri, Başına geçirdikleri dikenleri kırmızı renklendirme belli ediyordu. Marie'nin sevmek, onurlandırmak ve itaat etmek üzerine vereceği yeminler ölümcül günahlardı. Ak-mermerden İsa onun yalan söylediğini biliyordu.

O bir köy düğünü istemişti. Birçok kölenin ve eski kölenin yaptığı gibi "süpürge üzerinden atlamak istemişti ki böylece Jacques ile birlikte kendilerini karı-koca ilan edebileceklerdi.” Ancak Büyükanne böyle bir birleşmenin günahkâr ve "kâfirce" olacağını söylemişti. Marie’ye göre kilisedeki evliliği en büyük günahtı - Tanrı’ya inanıyorsan; artık bundan emin değildi. Kendisini sindirilmiş ve gergin hissediyordu bununla birlikte inancın ezici heyecanını hissetmiyordu. Beyaz azizlerin güçlere sahip olduğunu biliyordu; Büyükanne boşuna onlara hürmet göstermezdi. Ancak Marie başka tür ruhlara ilgi duyuyordu - Annesine ihtiyacı olan küçük siyah bir kızın dualarını duyabilecek ruhlara. (1995: 208)
\end{abstract}

Görüldüğü gibi, Marie’nin dünyasındaki etkin inanç ve bununla yoğun şekilde ilişkili olan kültürel kimliği, çevresini kuşatmış olan Katolik ve beyaz dünyadan oldukça uzaktır. Bu mizansen içinde Katoliklikle kurabildiği tek bă̆, mihrabın önünde diz çökmüş evlilik yemini verirken onun dürüst olmadığını bilen İsa Mesih’tir. Beyaz azizlerin de etkili olduğunu düşünmesine rağmen Marie'nin merak duyduğu ve takip etmek istediği ruhlar farklıdır. Kısa süre içinde, aslında hiç görmediği ve geçmişini 
bilmediği annesini aramak için geldiği New Orleans'ın onun için gizemlerle dolu olduğunu anlayacaktır. Böylece, Marie’nin Katolik dünya ile bu iç savaşımları olay örgüsünün gelişimine de bir çeşit önsemedir. Büyükannesi ve annesine dair bilmedikleri zaman içinde çözülecektir.

Marie'nin Katolik inancı ile ilgili bu sorgulamaları bir yandan sürmekteyken diğer yandan büyükannesi ve annesinin gizli geçmişini anlama çabası içinde köle inanışlarını de tanımaya başladığını görmekteyiz. Marie'nin inancını keşfetme çabası, doğanın koruması altında her türlü çatışmadan uzak büyüdüğü küçük cennetsi bataklı̆̆ı Teché'den çıkıp New Orleans'a yerleştikten sonra başlamıştır. New Orleans'a geldiği ilk gün büyükannesiyle birlikte Antoine DeLavier’in zulmüne uğraması Marie’nin naif ruhunda yara bırakmıştır. Bu olay sonrasında yakınlık kurduğu Jacques ile birlikte yaptığı New Orleans gezilerinden birinde limana henüz demir atmış yeni bir köle taciri gemisinden indirilen insanların manzaraları etkileyicidir:

Yüzlercesi oradaydı - pislik içinde siyah erkekler ve kadınlar, bacaklar birbirine kelepçelenmiş, geminin içinden tökezleyerek çıkıyorlardı. Saf dışkı kokusu Marie’nin başını öne eğdirdi. Bir deri bir kemik kalmış, ölmek üzere olan bazı vücutlar tahtırevan üzerinde taşınıyordu. Diğerleri gözlerini gölgeleyerek güneşin altında sızlanarak yürüyordu. Kırbaçlarla ilerletiliyorlardı.

Saçları bitlenmiş, keçe gibi olmuş ergen çağda bir kız çocuğu ağlıyordu. Toprağa yakarır gibiydi. Dizlerini düşürdü, yakarış içinde ellerini birleştirdi. "Damballah" diye ağıt yaktı.

Çağırdığı Tanrı mıydı? Ama Tanrı yerde değil gökyüzündeydi diye düşündü Marie. Tuhaf sesi çıkarmayı denedi: Damballah. Marie büyük sarsıntıyı duydu. Ruhunda hoş bir uyanış hissetti.

"Afrikalılar. Okyanus ötesinden geliyorlar."

"Ne?” İkinci kere Jacques’ın orada olduğunu unutmuştu. "Onları nereye götürecekler?"

"Oraya."

Acımasız sıcağın altında kafes gölgesizdi. Çıplak bedenler pislik içinde uzanıyordu. Bazıları balgam kusuyordu. Ayağa kalkamayacak veya pozisyon değisstiremeyecek kadar zayıf olanlar ya kendisinin ya da diğerlerinin üzerine idrarını yapmıştı. Şişmiş karınlar, kanayan diş etleri: köleler kapandaki yengeçler gibi sıkıştırılmıştı. Ergen kız çocuğu öne doğru tökezliyordu.

“Akşam satılmış olacaklar. Beyazlar için getir götür yapmak, taşımak, çalışmak için.” (1995:58-9)

Marie'nin ilk kez karşılaştığı bu sahne, öncelikle, ilk defa "Damballah" ismini duyması ve rrkının gördüğü muameleye şahit olması bakımından önemlidir. Teché ırmak boyunda büyükannesinin Katolik inancıyla yetişmiş olan Marie, henüz bu dinin kendi Afrikalı öz kültürünün inanışlarından farklılığını ayırt edebilecek bilgiye sahip olmasa da Katolikliğe karşı şüpheli yaklaşmaktadır. Ancak, limanda gördüğü bu manzara karşısında Marie, büyükannesinin kendisinden sakladığı gerçeklerin sadece eski inanışlarıyla ile ilgili olmadığını anlamıştır. Dehşet içinde Jacques'a bu insanların kim olduğunu ve onları nereye götürdüklerini sorması, Marie'nin bu yaşına kadar adeta var olmayan bir ülkede büyümüş olduğunu göstermektedir: "Marie anlamaya başladı. Büyükanne Efendisinin mutfağında kölelikten şikâyet etmişti, ancak resim daima muğlaktı. Onun tarihinin yüzü yoktu. Saklanmıştı. Marie köleliğin vahşiliğini asla şimdiki kadar hissetmemişti. Bu ıstırabı görmemişti, koklamamıştı, duymamıştı" (1995:59). Köle tacirlerinin New Orleans’a indirdiği ırkdaşlarının gördüğü muamele, Marie’nin beyaz adam ve dini hakkındaki gerçeklerle yüzleşmesini sağlamıştır. Marie, büyükannesinin onu geçmişin izlerinden korumak adına teşvikiyle isteksizce Jacques ile evlenir. Büyükannesi bu amaç için Marie’yi Teché'den çıkarmış, New Orleans'ın “özgür siyahîlerin” (“free people of color”) yaşadığı Haben's Haven adlı kasabaya taşımıştır. Ancak Haben's Haven'da da geçmişin izleri mesken tutmuştur. Torundan gizlenmiş olan geçmiş, yeni ev sahibeleri Annette'nin sinsice hazırladığı tuzakların avcunda Marie ve büyükannesini beklemektedir. Annette, Haben's Haven'a taşındıkları ilk günden itibaren Marie'nin 
kafasını karıştırmaya başlamıştır. Marie'yi, büyükannesi ve annesi ile ilgili bilmediği gerçeklere doğru onu yönlendirmeye başlayan Annette, aslında büyükannesinin eskiden çok ünlü bir Voodoo kraliçesi olduğunu ona ifşa etmiştir. Büyükannenin Katolikliği seçerek aslında aynı zamanda Afrika kökenini de inkâr ettiğini ima eden Annette, Marie'nin naif ruhuna isyan tohumları ekmiştir. Annesinin hayatta olup olmadığını bile bilmeyen Marie için geçmişin gizleri, gerçeği keşfetme uğruna, onu kötü niyetli büyücü John'a yönlendirecektir. Annette'nin gizlice anlaştığı Voodoo büyücüsü John, bir yandan - geçmişte annesine yaptığı gibi- Marie'nin avcuna düşmesini beklemektedir. Büyükanne, Marie'nin annesi ve Marie’nin üç kadın nesil olarak doğaüstü güçleri olduğu ortadadır. Voodoo büyücüsü John ve Annette, Marie'nin bu gücünü kendi çıkarları için kullanmak istemektedir. Annesinin bilinmez geçmişi ve Büyükannenin Katolikliğini karalayarak Marie'yi ikna eden Annette, onu quadron denizci Jacques ile evlenmeye ikna eder. Çünkü Voodoo kraliçesi olmak için öncelikle kadınlık evresine geçmesi gerekmektedir. Köle inanışının tanrısı Damballah böylece Marie'nin ruhuyla irtibata geçecektir. Marie, düğün gecesinden sonra Jacques’i terk edip, büyücü John ile birlikte gitmeye karar verir. Haftalarca John'un kulübesinde saklı tutulduktan sonra ayin için beklenen gün gelir. Marie, Damballah ile buluşacak, böylece annesi ile ilgili gerçekleri de öğrenecektir. John Marie’yi bu yalana ikna etmiştir. Dambalah'ın ne olduğu ve bu ayinine dair betimlemeler, Afrika kökenli inanışın içeriğini açıklamaktadır:

Sevilen ve ruhların en güçlüsü olan Damballah. Yeryüzünde yavaş yavaş süzülerek ilk yaratılmışlara hayat üfleyen Damballah. Bir bereket tanrısı: Yeryüzünün ve suyun hükümdarı. Doğan ve kendisini yeniden doğuran tanrı.

Mihrabın üzerinde mumlar, altıgen ve bir dairenin içinde kabataslak bir yılan resmi vardı. Yılanın üzerinde bir gökkuşağı. Mihrabın tabanında tanrıların giysileri ve süslemeleriyle dolu bir kutu vardı, büyülenmiş olanlar tanrıları evinde gibi hissettirmek için giyinirlerdi. (1995: 119)

Damballah tanrısının işlevi yaşam döngüsünün sürekliliğini sağlamaktır. Bu işlevin sembolize edildiği ayinde, Damballah sadece kadın bedeniyle vücut bulabilir, çünkü kadın bedeninin doğurganlığı bu tanrının yeryüzüne bereket getirmesiyle eş anlamlıdır. Marie için ise Damballah, geçmişin gizemlerini öğrenmek ve annesiyle buluşmak manasına gelmektedir. Marie bu amaçla Voodoo kraliçesi olmayı seçmiştir. Böylece, Marie için Voodoo, onu, geçmişinin izinde aradığı aile tarihi ile ilgili gerçeklere adım adım yaklaştıran ayinsel bir büyüme öyküsü olmakla birlikte, etnik kimliği ve ırksal tarihine karşı da bir uyanışı temsil etmektedir. Marie'nin hilekâr büyücü John ile birlikteliğinde kısa sürede anladı̆̆ı gibi Voodoo elbette bir aldatmacadır. Her inanışta görülebildiği gibi insanların zaafları ve cehaletini sömüren, bundan beslenen batıl inançlardan biridir Voodoo. Bununla birlikte, yazar Jewel Parker Rhodes, Voodoo kraliçesi Marie Laveau'nun yaşam öyküsünden yola çıkarak, Voodoo inanışını, Güney Louisiana'nın geçmişiyle bağ kurduran kültürel bir temsil olarak ortaya koymaktadır. Günümüzde artık sadece New Orleans turistik objeleriyle popüler olan Voodoo temsillerinin ve açlk hava kültür müzelerine dönüştürülmüş Louisiana eski köle çiftliklerinin New Orleans ziyaretçilerini büyülediği gibi, bu roman da okuyucuyu mekânın tarihsel dokusu ve yaşanmışlığına götüren anlatısal bir Louisiana tarihi sunmaktadır.

Romandaki ırk ve kimlik algısı için bir diğer örnek, yarı Anglo-Amerikan, yarı Louisiana Kreolesi olan Louis DeLavier ile "saf kan" Kreole olan Antoine DeLavier arasındaki kültür çatışmasıdır. Louis DeLavier, aynı soyadı taşıyan kuzeni Brigette DeLavier ile nişanlanmak için New Orleans'a Kuzey'den yeni gelmiştir. Protestan bir anneden doğan Louis DeLavier, Kuzey'de yetişmiştir. Protestanlığın katı yaşam biçiminden bıkmış, yetişkinliğinde New Orleans'a yerleşmiştir. Ancak henüz köleci bir toplum olan New Orleans'ta Louis DeLavier'in Kuzeyli karakteri ağır basacaktır. Louis DeLavier'in Marie Laveau ile New Orleans'ta karşılaştı̆̆ ilk gün yaşananlar, Kuzey ve Güney arasındaki bu keskin 
mezhepsel ve siyasi farklılığın bir örneğidir. Marie ve büyükannesini Siyah Yasasından korumak isteyen melez denizci Jacques'e karşı Antoine DeLavier’in gösterdiği ölçüsüz şiddet karşısında Louis DeLavier öfkelenmiştir:

Louis DeLavier öfkeliydi. Kuzeni Antoine, Güney ile ilgili nefret ettiği her şeyi temsil ediyordu. Kendi iktidarı ile ilgili vahşi, hissiyatsız ve kibirli Antoine, Güneyli beyefendi simgesiydi. Louis fiziksel olarak kuzeninin dengi olmadığını biliyordu. Ama Antoine'u spor için bir adam öldürmekten alıkoymanın bir yolu olmalıydı. Bağırdı, "Antoine buna bir son vermeni ısrar ediyorum."

"Canın cehenneme Louis."

Louis hızla Antoine'nun yolunu kesmek için hareket ederek arabadan atladı. "Sana karşılık veremeyeceğini biliyorsun."

"Biraz ciğeri olsaydı karşılık verirdi."

"Hiç onurun yok mu?"

“Sendeki kuzeyli onurundan yok. Biz siyahların küstahlığını tolere etmeyiz.” (1993: 50)

Louis ile Antoine arasındaki bu kültürel ayrım, kuzenler arasında geçen bir diğer mezhep tartışmasında daha da belirgin hale gelir. Brigette ve Antoine, kuzenleri Louis'in Güneyli hanımefendilik ve beyefendilik hakkındaki fikirlerini sorarlar. Louis'in Kuzeyli dokundurmalarına cevaben Antoine, Brigette ve Louis arasında şöyle bir diyalog geçer:

Antoine cevap verdi, "En azından korkak bir Püriten değilim.”

"Püriten değil, Protestan. Kuzeyli DeLavier ailesi Protestandır. Ancak

sana söylemiştim" dedi Louis, "Hiçbir inancı kabul etmiyorum."

“İşte, Brigette.” Antoine alayla dudağını büktü. "Tanrısız bir kuzen.”

"Hayır, sanırım hala Tanrıya inanıyorum. Beni dehşete düşüren dindar iki yüzlülük.”

“Katolikliğe dön,” dedi Antoine, başparmağını Louis’in göğsüne gömerek.

"Kurtuluşa erebilirsin."

Louis, alaycı bir ciddiyetle "Ve senin gibi mi olurum?” Dedi. “Böylece tüm hafta boyunca içerim, zina yaparım, küfrederim ve kumar oynarım. Pazar günü günah çıkarırım, on tane Hail Mary duası okurum ve Pazartesi günü tekrar baştan günah işleyecek kadar arınmış olurum. Ne âlâ. Dinin çok yorucu olmall." (1993: 53)

Kuzeyde Protestan eğitimi almış olan Louis'in deizminin, Anglo-Amerikan Aydınlanmacı kurucu figürlerinin de içinde yetişmiş oldukları Protestan kültürün bir yansıması olduğu düşünüldüğünde, kendisi ve Antione arasındaki kültürel çatışmanın esasen mezhepsel olduğu aşikârdır. Roman boyunca farklı etnik ve sınıfsal kimlikler arasında yoğun olarak inanışlar bağlamında hissedilen bu kültürel çatışma, bir diğer yandan Louis DeLavier'in New Orleans Voodoo kraliçesi Marie Laveau'ya duyduğu tutku üzerinden, hiyerarşik üstün özne ve nesne karşılıklı zıtlığı bağlamında verilmiştir. New Orleans'ta karşılaştıkları ilk gün yaşananlardan sonra Marie, Louis DeLavier’in belleğinde yer etmiştir. Marie'nin yüzündeki naif ifade ve sadeliği, bir diğer yandan ruhunun bu özellikleriyle bütünleşen egzotik güzelliği, Louis DeLavier’i büyülemiştir. Kuzeni Brigette ile nişanlı olmasına rağmen, bu olaydan sonra Louis DeLavier Marie’yi unutamaz. Uzun süre New Orleans sokaklarında bu cennetsi güzelliği arar. Çaresizdir:

Onu bulamıyorum. Antoine'nın Pazar Meydanı'nda sataştığı kadını bulamıyorum. Yemin ederim her köleye, uşağa hatta Caddede gördüğüm yabancılara bile sordum. Kimse tarif ettiğim siyah kadını tanımıyor. Kavurucu sıcak yaz, mevsim normalleri dışında serin bir güze dönüştü. Kahverengi kızımla karşlaştı̆̆ım o bahardan beri bir yıl geçmiş olabilir mi? (1993: 132) 
Alışmaya çalıştığı New Orleans'ın ırkçılık gibi karanlık tarafları bir yana, beyazların adaletsizliği, kölecilik ve her türlü kültürel çatışma Louis DeLavier’in bu yeni mekâna uyumunu zorlaştırmaktadır. Evlendikten sonra kuzeni Brigitte DeLavier’in yüzeyselliği ve menfaat üzerine kurduğu aile bağları Louis’i kendisinden daha da uzaklaştırmıştır. Kocasının bu mesafeliliğini hazmedemeyen Brigette, Marie'yi çoktan avcuna düşürmüş olan Voodoo büyücüsü John'a Louis'e büyü yaptırmak için başvurmuştur. Böylece, toplum içindeki nüfus ve zenginliklerine dayanarak, sadece siyah irktan olduğu için Jacques Paris’i öldürme hakkını kendinde görebilen Brigette ve Antonie, bu sefer Louis üzerinde etki kurabilmek için küçümsedikleri siyahlara ve inanışlarına muhtaç kalmıştır. Brigette ve Antoine’nın Voodoo ile kurduğu bu bağın yanı sıra, aslında benzer şekilde, Louis de Marie’yi bulmak için çareyi bir Voodoo büyücüsüne başvurmakta bulacaktır. Başta Katoliklik olmak üzere, genel anlamda dinin çürümüş bir kurumsal yapı olduğunu düşünen deist Louis DeLavier’in Marie’ye ulaşmak için Voodoo'ya başvurması ironiktir: "Uşağım Charles Voodoo'nun kayıp birini bulmaya yardımcı olabileceğini söylüyor. Elbette bu bir saçmalık. Voodoo ilkel bir din. Yine de denemek istiyorum” (1993: 132). Marie'yi bulmak için başvurduğu Voodoo, Louis'e beklediğinden fazlasını sunacaktır. Louis, bu inanış ile tanışarak, özgür siyahîler başta olmak üzere, Afrika kökenli nüfusun toplumsal gerçekliği ile karşılaşmıştır. Sarsılmaz usçuluğunun kibiri ile ziyaret ettiği bir Voodoo ayini, Louis’i farklı bir kültürel tecrübe ile buluşturmuşstur:

Kapı deliğinden ev kölelerinin gösterişten uzak ayinlerini izledim. Hiç ilgi çekici değildi: davul eşliğinde dans, biraz kan akıtma, fiçılarca şarap içme. Hiç etkilenmemiştim. Köleler büyücülük oyunu oynayan yaramaz çocuklara benziyordu. Charles, "liderleri, Kraliçeleri yok. Bu yüzden kayda değer tanrllar gelmiyor" dedi.

Voodoo'yu ilkel olarak tanımlamak belki de benim dar-kafalılığımdır. (Tüm dinlerle ilgili şüphe içindeyim. Hepsinin ikiyüzlülükle bozulmuş olduğuna inanıyorum.) Ancak bir Voodoo büyücüsünün trans hallerinin coşku içinde konuşan bir Shaker'dan farkı var mıdır? Voodoo dansının herhangi bir Protestan kilisesinde şarkı söylemekle benzerliği yok mudur?

Voodoo Katolik ayininden kesinlikle çok daha az karmaşı geliyor kulağa. Papa inancına karşı özel bir önyargım olduğunu kabul etmeliyim. Karımın itiraf etme ihtiyacını hayret verici buluyorum. Ayrıca John adında bir Voodoo doktoruna danışmasını da ilginç buluyorum. İki dini nasıl bir araya getirdiğini kafamda canlandıramıorum.

"Her Louisianalı Katoliktir" der Charles, "ve her Katolik Voodoo büyülerine inanır."

Voodoo hakkında bir dizi makale yazmak ilginç olabilir. Amerika din özgürlüğü üzerine kurulmamış miydı? (1993: 132)

Kapı deliğinden Voodoo ayini izleyen Louis DeLavier figürü, kölelerin nesne durumlarını güçlendiren klişe bir beyaz adam tutumunun temsilidir. Aralarına karışmadan, dışarıdan izlemesinin verdiği iktidar konumu, Louis'in Voodoo hakkında yargıda bulunmasına olanak sağlamaktadır. İzlediği ayinde, davul ezgileri eşliğinde dans eden, bolca şarap içen, bir yandan da kurbanlıkların kanını akıtan köleler, ona büyücülük oynayan yaramaz çocukları hatırlatır. Bu manzaradan hiç etkilenmediğini ifade eder. Ancak sonraki düşünsel sorgulamaları dikkate değerdir. Belki de kendi dar kafalılı̆̆ından dolayı Voodoo geleneğini ilkel bir inanış olarak algıladığını düşünür. Tüm dinlerin çifte standart uygulamalarıyla insanları bilinmeze sürüklediği gerçeği hakkında sabit fikir olduğunu yineleyerek, Voodoo ayininde coşanların aslında Shaker tarikatından ya da kilisesinde ilahi söylerken kendinden geçen Protestanlardan farklı olmadığı düşüncesine varır. Üstelik Voodoo ayininin Katolik ayinlerinden çok daha az karmaşık olduğunu düşünür. Ayrıca Papa inancına karşı mesafeli duruşunun sebebi, bir Katolik olan eşi Brigette'in Voodoo şifacısı John'a başvuruyor olmasıdır. Bu düşüncelerin ardından, Louis kendi durumunu da sorgulamaya başlar. Öncelikle Katolik bir kadınla evlenerek nüfusun çoğunluğunun köle olduğu bir şehre yerleşmesi Louis'in Kuzeyli Anglo-Protestan kimliğiyle kökten uyumsuz bir tercihtir. Sadece bir kere gördüğü ve hiç tanımadığı melez bir kadını bulmak için Voodoo ayinlerini gezmesi de 
Güney kültürünün sınıfsal ve ırksal baskısı karşısında alternatif alan açan Kreole gibi bir sınır kimliğin bu toplumsal dinamiklerin çözülmesinde ne derece etkili olduğunu göstermektedir:

Charles bir Voodoo Kraliçesi hakkında dedikokular olduğunu söylüyor. Duyduğuma göre gerçek bilgeliğin yılan tanrısı olan Damballah'ın irtibat kuracağı ve ziyaret edeceği kadar güçlü olan birisiymiş.

Rasyoneliteden başka bir Tanrıya inanmiyorum.

Bu yaptığım akla uygun mudur merak ediyorum?

Sevmediğin Katolik bir kadınla evlenmek, nüfusun çoğunluğunun köle olduğu bir güney şehrinde yaşamak, aşık olduğum ama tanımadığım bir başka kadını bulmak için Voodoo Kraliçesiyle konuşmaya mazeret üretmek akla uygun mudur? (1993: 132-3)

Louis, usçuluktan başka bir Tanrı tanımadığını ifade ettikten sonra, içinde bulunduğu hali de sorgular. Aslında zaman içinde anlayacaktır ki, ümitsizce ve kendi ile çatışmalar içinde âş̧k olduğu Marie'yi araması, usçu yönüyle Tanrı kavramında aradığı idealin ete kemiğe bürünmesinden başka bir şey değildir. Aynı usçu yön, ona, Güney’in kölecilik ve din gibi kemikleşmiş kurumlarını sorgulatır. Louis'e göre tek kaynă̆ı Tanrının esini olan vicdan kurumsal din ve uygarlığın baskısı karşısında daha güçlüdür. Bununla birlikte, Louis, usçuluğunun potansiyelinde mevcut olan indirgemeci yaklaşım ve hiyerarşik tanımlamalardan vazgeçer. Böylece, Voodoo ayinine atfedilen "ilkellik," aslında iktidarın yarattı̆̆ korkuların yönettiği tarih ve kültür algısının bir ürünüdür. Bu bağlamda Yapısalcılık Sonrası dil kuramcılarından Julia Kristeva'nın "iğrenç öteki” ("abject other”) kavramını düşünmeden geçemeyiz. Sözlük anlamıyla, "abject," "iğrenç” ya da "bulantı veren” anlamına gelmektedir. Kristeva, Korkunun Güçleri: İ̆̆rençlik Üzerine Deneme adlı çalışmasıyla, beden salgıları, hastalık, cinsellik, doğum, ölüm gibi doğal süreçlerin kültürde ötekileştirilmiş özne konumlarını, dilin yapay düzeninde bilinçdışı hiyerarşinin korkularını sembolize eden gerçeklikler olarak yorumlamıştır. Kristeva için bu kültür ve dil bağlamındaki abject, Jacques Lacan'ın öne sürmüş olduğu Sembolik Düzende kırılma yapma potansiyeli ile daima bir tehdit olarak görülmüş ve baskılanmış bir unsurdur. Romandan seçilen bölümde, Louis önce refleks bir önyargı içinde Voodoo ayini yapanları "büyücülük oynayan yaramaz çocuklara" benzeterek ötekileştirir. Bunun ardından aklıselim düşününce aslında bu ayini Shaker tarikatı ya da Protestan kiliselerindeki coşkulu topluluklardan farklı bulmadığını ifade eder. Biraz daha fazlası vardır bu yorumda. Louis, Voodoo ayininin Hristiyan ayinlerinden daha anlaşllır olduğunu düşünür. Bu bağlamda, Voodoo, kilisenin yaptırımlı düzeninden bağımsız, öncelikle, doğal mekânlarda gerçekleştirilmektedir. Sunaklarda akıtılan kurbanlıkların kanı, dans ve davul ritmi, Voodoo kraliçelerinin irtibat kurduğu tanrıların doğadaki sembolizmi, tüm bu unsurlar Batı uygarlı̆̆ının Sembolik Düzeninden uzaktır. Voodoo, doğada ve doğaüstü bağlamlardaki düzensizliği kutsayarak, müritlerine belirsizliğin hüküm sürdüğü bir sınır alan açar ve böylece hâkim düzene meydan okur. Voodoo inanışının takipçileri, ayinlerinde, dış gerçeklikte ulaşamadıkları iktidar, kanun ve düzen koyucu toplumsal statülerin dışladığı öteki konumlarına özgü alternatif bir mekân aidiyetine kavuşmaktadır.

Görüldüğü gibi, Jewel Parker Rhodes'un Voodoo Dreams romanındaki karakter ögeleri Güney Louisiana yerel kültürünün kimlik unsurları hakkında zengin bir malzeme sunmaktadır. Son olarak, romandaki Güney Louisiana Kreole kimliği üzerine bir örnek daha verilecektir. Marie'nin büyükannesi, onu korumak adına, geçmişle ilgili pek çok sır saklamaktadır. Ergin çağına gelene kadar, Marie’yi Teché ırmak boyu gibi insanlardan uzak bir doğal sığınakta büyütmesinin sebebi, ailenin maruz kaldığı kötülüklerin bir gün gelip küçük Marie'yi de bulmasından endişe etmesidir. Bununla birlikte, ailenin Voodoo geçmişini Marie'den saklaması ve onu atalarının bu eski inanışından uzaklaştırmak için Katolik inanışıyla yetiştirmesine rağmen, büyükanne kim olduklarıyla ilgili bilgiyi torunundan esirgemez: 
Ve Marie Büyükannesinin her dediğini dinlerdi, susamış bir deniz süngeri gibi içine çekerdi.

"Biz melez kanız." Büyükanne yüzlerini yan yana bastırarak eğilirken sesi ahenkliydi. "Kreolelerin kanı Fransız kraliyet neslinden. Mulatto'ların kanı Afrika kraliçesinin neslinden. Ve Muskogean savaşcısının kanı bu karışımın gücünün saltanı için var.”...

Marie Büyükannesinin yüzü dışındaki hiç bir yüzle bağ kuramadığı için sıkıntı duydu. Hayatında hiç Afrikalı ya da Fransız hanedanından birisini görmemiști. Kızılderililer zaman zaman avlanırken yanından geçip giderdi. (1993: 16)

$\mathrm{Bu}$ diyalogda, büyükanne için esas olan konu, bu melezliğin barındırdığı kimliklerdir. Ancak bu kimlikleri taşımanın verdiği özgüven büyükanneye ayrıcalıklı bir konum sağlamakta yeterli olmamıştır. Güney Louisiana tarihinde, birbirleriyle sonu gelmez bir çatışma ve savaşım içinde ilişki yürütmüş olan Fransı, İspanyol, Anglo-Amerikalı, Afrikalı ve Yerli Amerikalı kimlikleri, sömürge mekân koşullarında ortak bir kanda birleşerek yeni bir kimlik ortaya koymuştur. Marie’ye etnik kimliği ile ilgili bu bilgiyi verdikten sonra, büyükanne, eteğine tutturmuş olduğu tesbihi eline alırken tesbihin başındaki minik çarmı baş parmağını kanatır. Bu esnada, büyükanne, kendisinden önceki ilk üç neslin köle olduğunu ve Marie’nin ailenin özgür doğan ilk nesli olduğu gerçeğini unutmaması gerektiğini söylemektedir. Bu arada kanayan parmağını emerken, tekrar "melez kan" konusunu açar: "Büyükanne başparmağından kanı emdi. 'Melez kanlar. Bizim tarihimiz ve gücümüz.' Kırmızı yatak örtüsünü lekeledi. 'Kan diridir. Daima" (1993: 57). Burada, "Melez kan tarihimiz, gücümüzdür" ifadesi önemlidir. Parmağından damlayan kanın yatak örtüsünde bıraktığı leke üzerine, büyükannenin, kanın canlı olduğunu eklemesi, bir önceki cümlesinde melezliğin tarihi ve iktidarının halen yaşamakta olduğu ifadesini güçlendiren bir metafordur. Kan lekesinin uzun zaman geçse bile canlılı̆̆nı kaybetmemesi gibi, sistemin ve tarihin baskılarına rağmen, melezlik de öteki konumunda bile kültürdeki iktidarını koruyabilmektedir. Etnik kimliklerin günümüze dek sürdürmekte olduğu siyasi ve kültürel mücadeleler sonucu meşruiyet kazanmış olan melezlik ya da modern tanımıyla Kreoleleşme gibi liminal kimlik algıları, Güney Louisiana yerel kültürünü, ABD’nin üst kimliği olan Anglo-Amerikan sistemi içinde kabul gören bir konuma getirmiştir. Bu bağlamda, Voodoo Dreams romanının Marie Laveau'nun yaşam öyküsü üzerinden ortaya koyduğu melez ya da diğer bir deyişle, Kreole inanış ve kimlik ögeleri, ana akım Amerikan kültürüne karşı direnişinin temsilidir. Romandaki Marie karakteri için de bu geçmişin izini sürebileceği tek araç Voodoo olacaktır. Marie için büyükannenin kendisine aktırmış olduğu bu melez kan konusu, Teché ırmak boyunda Güney Louisiana'nın kültürel ve toplumsal gerçeklerinden izole edilmiş yaşantısı nedeniyle henüz hiç bir anlam ifade etmez: "Marie, karmaşık desenli yorgan misali, kanının nereye aktığını hayal etmeye çalışarak saatlerce elindeki kıvrımlı damarlara bakmıştı. Aynada Kreole ya da mulatto görememişti. Kölelik masalları Büyükannenin İncil karakterleri kadar uzaktı" (1993: 17). Güney Louisiana'nın tarihsel bağlamında en belirgin şekilde varlığını yitirmiş olan kimlik Yerli Amerikalı kimliğidir. Yerli Amerikalılar Avrupalı sömürgeci yerleşimcilerin Yeni Dünya'daki hâkimiyetinden itibaren on dokuzuncu yüzyılın sonuna doğru ABD'nin kıtasal yayılmasını tamamladığı sürece kadar sürekli savaşlar, katliamlar ve sürgüne maruz kalmışlardır. Çeşitli eyaletlerin rezarvasyon kamplarına dağıtılmış olan kabile soylarının yeni nesilleri günümüzde sistemin kendilerine sağladığı sınırlı yaşam alanlarında kültürel mücadelelerine devam etmektedir. Güney Louisiana'daki Yerli Amerikalı kültür tarihi ve konumu, ABD genelindeki Yerli Amerikalıların durumundan farklı değildir. Ancak, ABD’nin diğer kültürel bölgelerinden farklı olarak, Yerli Amerikalılık, Güney Louisiana'nın ırksal ve kültürel melezleşme sürecinde ortaya çıkan Kreole kimliğinin bir diğer rrksal ögesidir. Büyükannesinin Marie’ye aktarmaya çalıştığı bu Yerli Amerikalı kimliği, Muskogean savaşçısı olan dedesi Sachwaw'ın mirasıdır:

Büyükanne parmaklarını gözlerine bastırdı. Geçmişten görüntüler ölmüş ruhlar gibi canlanmıştı. Çok uzun zaman önce. Bir Kızılderili. Uzun boylu Muskogean savaşçısı. Sachwaw diye bilinirdi. Nasıl göründüğünü güçlükle hatırladı. En iyi hatırladığı şey onun tarafından sevilmenin nasıl bir duygu 
olduğuydu. Marie’ye bundan daha iyi bir miras verebilir mi? Yasal bir eş. Kendisinin yaptığı gibi, sevilmesindense kırbaçlanmasını tercih eden kıskanç köleler ve intikam dolu bir Efendiden kaçarak, ormanda saklanmak zorunda olmamak (1993: 27).

Mona Lisa Saloy'un Red Beans and Ricely Yours (2005) adlı şiir kitabında da Güney Louisiana'daki inanışların melezliği özgün kültürel bir kimlik olarak ifade edilmektedir. Saloy da Jewel Parker Rhodes'un Voodoo Dreams romanına konu olan Voodoo kraliçesi Marie Laveau'ya bir şiirinde yer vermiştir. "The Ballad of Marie LaVeau" adlı şiirinde, Marie Laveau'nun yaşamı ile özdeşleşmiş, New Orleans kültür tarihinde abideleşmiş bir gelenektir Voodoo. Saloy'un bu şiirinde, Rhodes'un romanındaki Louis DeLavier karakterinin Voodoo ve Hristiyanlık bağlamında sorguladığı Aydınlanmacı Batı bilgi bilimi gerilimine alternatif bir bakış açısıyla Voodoo'nun güçlü bir iktidar aracı olarak temsil edildiğini görmekteyiz. Şair Saloy, Katolik-Kreole kültürünün barındırmış olduğu Katoliklik ve Afrika kökenli inanışların melezliğini şiirin ilk mısralarında Marie Laveau'nun mezarına ziyaret adabı ile ifade etmektedir. Ziyaretçilerin geldiklerinde Marie Laveau'nun mezar taşına üç kere vurmasını, ona taze çiçekler getirmesini söyleyen şair, parlak gümüş renkli mumlar ve haçların halen Marie Laveau'nun yaşamıyla bütünleşmiş Voodoo sunakları için yanmakta olduğunu söylemektedir. Şiirin takip eden nakarat dizelerinde Marie Laveau'ya Kreole diyalektinde seslenişte bulunmaktadır. Fransızca ve Afrika dillerinin karışımı olan bu dil, Güney Louisiana'nın Amerikan tarihinden çok daha eski dönemlerinde bir araya gelmiş sömürge nüfuslarının tarihini temsil etmektedir:

Üç kere vurmalısın.

Toplanmış taze çiçekler getirmelisin

mezarına Marie LaVeau'nun.

Hala onun Voodoo adakları için yanan

parlak gümüş mumlar

yontulmuş çarmıhlar.

Yé Yé Mamzelle Marie,

Li Konin Tou, la gris-gris.

Yé Yé Mamzelle Marie,

Yé Yé Mamzelle Marie,

Li Konin Tou, la gris gris (Saloy, 2005:58)

Saloy’a göre Güney Louisiana'nın çok-kültürlü yapısını bir arada tutan ırk sadece siyahî ırk değildir. Bir diğer ifade ile buradaki kimliklerin siyah ve beyaz gibi net sınırla birbirinden ayrılması mümkün değildir. Güney Louisiana'daki Kreole tanımının açılmış olduğu bölümde de ifade edilmiş olduğu gibi, anakent sömürgeci hanedanlar ile sömürgeleri arasındaki fiziki ve kültürel mesafe nedeniyle, zamanla sömürgelerde doğan sömürgeci nüfusta belirgin yeni karakter özellikleri ortaya çıkmıştır. Sömürgeci anakentler açısından bu yeni karakter unsuru daima siyasi bir tehdit potansiyeli taşımıştır. Kuzey Amerika'daki İngiliz sömürge nüfusunda da gözlemlenmiş olduğu gibi Güney Louisiana Fransız ve İspanyol sömürge tarihinde bölgede yaşayan yeni Fransız ve İspanyol Kreole nüfusu Avrupa'daki siyasi çatışmalardan ve Eski Dünya kültüründen uzak yeni bir yaşam deneyimi içindedir. İlk sömürge dönemlerinde Louisiana'daki sömürgeci yerleşimcilerin ağırlıklı olarak erkek olması sebebiyle ortaya çıkan yeni melez neslin siyasi ve toplumsal olarak meşruiyeti "özgür siyahîler" (free people of color") 
gibi bir rrksal kategorinin doğmasına neden olmuştur. Güney Louisiana'da ortaya çıan bunun gibi tanımlamalar ırklar ve kültürler arası melezliği ve belli bir ölçüde de olsa toleransı da getirmiştir. Jewel Parker Rhodes'un Voodoo Dreams romanında da görüldüğü gibi hemen hemen her beyaz Kreole erkeğin melez bir metresinin olması, New Orleans'ta beyaz Kreolelerin bu tercihi için işletilen Melez Salonlarının ("Quadroon Balls") yaygınlığı, Amerikan Güney bölgeleri arasında Güney Louisiana'ya farklı bir kültürel kimlik getirmiştir. Benzer şekilde, Saloy'un "The Ballad of Marie LaVeau” adlı şiirinde, Voodoo ayinlerinde siyahlar ve beyazlar bir aradadır: " tozun içinde / kadınlar ve erkekler / Siyah ve beyaz/ bir pınarın etrafında dans ediyorlar. / Gece boyunca Kreole şarkıları söylüyorlar, Marie'nin gözleri ateşe dikilmiş"(2005: 58). Böylece, bu dizelerde, Marie Laveau'nun Voodoo ayinleriyle abideleşmiş olan New Orleans Kreole kültürü kadın-erkek ve siyah-beyaz gibi karşılıklı zıtlıkları bir araya getirmiştir. Şiirin devam eden dizelerinde Marie Laveau figürünün egzotizmi resmedilir:

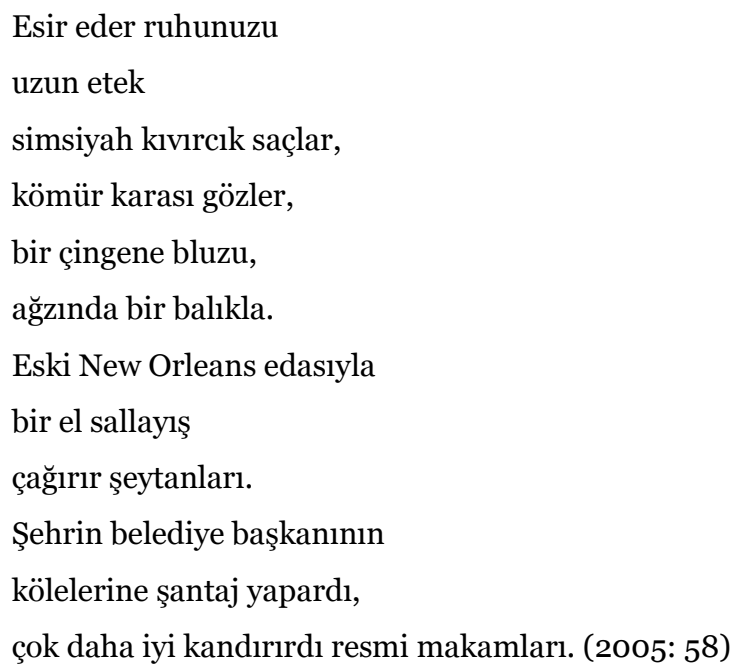

Kölelerine yaptığı büyülerle New Orleans bürokratlarını bile dize getiren Marie Laveau'nun hâkimiyeti, sistemin ötekisi olan herkes için bir ümittir. Zalim efendisinden çeken köleler, âşığını kendine bağlamak isteyen, hastalığına derman arayan beyaz ve siyah Kreole kadınlar, erkekler için Marie Laveau'nun ayinlerinde sınır, yasak, ırk ve sınıf yoktur. Bastırılmış tüm varlı̆̆ın kendisine yaşam alanı açabildiği, akıl ve akıl-dışının bir denge içinde birleştiği bir mekândır Laveau'nun büyü ayinleri. Laveau'nun melez, kaba tabiriyle "kırma ırktan" olma durumu da manidardır. Ne sadece siyah ne beyaz; ne sadece Afrika ne de Yerli Amerikalı ama hepsidir Laveau. Michel Foucault'nun ifadesiyle iktidar ile tebaası; efendi ile kölesi gibi diyalektiksel ilişkilerin çözüldüğü kenar kimlikler daima hâkim olanı devirme potansiyeli taşımaktadır. Bu yüzden iktidar ilişkileri, özünde, tepeden aşağıya değil aşağıdan yukarıya doğru da yönlenir. Beyaz toplumun dışladığı ama barındırdığı; tiksindiği ama aynı zamanda haz duyduğu bir yapıdır Voodoo. Mona Lisa Saloy'un da ifade ettiği gibi, Voodoo ayinleri ve Voodoo Kraliçesi kimliği ile New Orleans'in karnaval figürlerinden biridir Marie Laveau:

Eski New Orleans usulünde evlilik bağları

iş anlaşmalarıydı.

Fransız beyefendilerinin

melez sevgilileri vards;

Marie bilirdi tek tek hepsini ve sebebini.

Ĕ̆relti otlarıyla saklanmış

suyun üzerinde, 


\begin{abstract}
onun Voodoo cenneti
Beyaz Evi

ata ayinleri düzenlerdi, gece boyunca yılan gibi dans ederdi, diri diri boğazlanmış tavuğun kanını içerdi. Marie küçük bir mum kutusunu eline aldı, Onu tüylerle kapladı,
\end{abstract}

Bir araya getirmek için serbest kalmış kalpleri ve kemikleri

zift karası gecede

bir eğimin üzerine yerleştirdi. (2005: 59)

Eski New Orleans'ta Fransız Kreole beyefendilerin evlilikleri yüksek sınıf aile bağları ile kurdukları birer iş anlaşmasıdır. Hemen hemen hepsinin mutlaka New Orleans'ta melez bir metresi vardır. Marie hepsini tanır. Ayinlerini yaptığı "Beyaz Evinde"("Maison Blance") atalarıyla bağ kurar, kurbanlarının kanı ile büyüye çağırır ruhları. Voodoo kraliçesinin bu karnaval hali, resmi Katolikliğin ilkelerini bozmakla kalmayıp, şehrin katı sınıfsal ve ırksal duvarlarını yıktığı bu yasadışı inanışla otorite ortaya koyarak iktidar-özne hiyerarşisini ters çevirmiştir. Sadece sisteme aykırı değil aynı zamanda güçlü bir başkaldırı potansiyelidir Laveau:

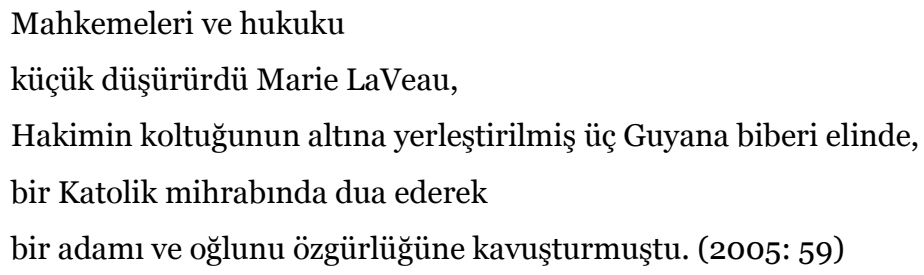

"Hâkimin koltuğunun altına bırakılmış üç Guyana biberi elinde, Katolik mihrabında dua ederek," babaoğul iki kölenin özgür bırakılmasını sağlayan Marie Laveau, hem Katolikliği hem de yasaları küçümsemektedir. Voodoo, resmi, kurumsal olan hâkim kültürü, yasaları aşan bir alt kültür olarak hem Katolik dinine hem de yasalara başkaldırmaktadır. Her şey Marie Laveau'nun elindedir. Bu bağlamda, kült haline gelmiş imajı ile Voodoo Kraliçesi'nden öte kültürel bir mirastır New Orleans'ın Marie Laveau'su. Sonuç olarak, bu bölümde Jewel Parker Rhodes'un Voodoo Dreams romanı ve Mona Lisa Saloy'un Red Beans and Ricely Yours adlı şiir kitabında, Güney Louisiana'daki rrk ayrımlarının Katoliklik ve Afrika-Karayip kökenli pagan inanışların melezliği ile esnediği ve bu inanışların merkez iktidar alanı dışında alternatif bir alan açtığı görülmektedir.

Mona Lisa Saloy'un Red Beans and Ricely Yours şiirlerinde bu ırk çatışmalarının çözümü ön plana çlkmaktadır. Güney Louisiana ve New Orleans'ın mekân olarak barındırmış olduğu sömürge kültür tarihi, sömürgecilik ve köleciliğin vahşi izlerinin yanı sıra, tüm bu çatışmaları çözen yeni alternatif kültür ögelerini de beraberinde getirmiştir. Saloy, "My Mother's the Daughter of a Slave" adlı şiirini köleciliğin kaldırılmasından sonraki ilk nesil özgür siyahî ırktan olan büyükannesine atfetmiştir. Şiirde 1907'de şehirli siyah kadın olmanın yarattığı baskı ile birlikte aynı dönemin New Orleans'ının toplumsal dokusunu da betimlemektedir. Şehrin Caz müziği ile yankılanan kenar semtlerinde yüksek sinıftan insanlar gezinmektedir. Afrikalı kölelerin çeşitli kültürel ritüellerinde, sömürge kültürünün Louisiana'da buluşturduğu farklı Afrika-Karayip uzantılı inanışlar ve diller bir araya gelmiştir. Bu 
bağlamda ırkların bir-arada oluşunun yaratmış olduğu melezlik müzik kültüründe de ortaya çıkmıştır. Böylece, köleciliğin kaldırılmasından sonra siyahî nüfus için devam eden ağır şartlar ve ırkçılığın baskısından uzaklaşmak için, Chicago ve New York gibi Kuzeydeki endüstriyel şehirlerin aldığı siyah nüfus göçü ile yirminci yüzyıl Amerikan şehir kültüründe Caz müziği öteki konumundaki Afrikalı Amerikalı kimliğe yeni bir alan açmıştır.

Şehirli-Siyah kadının ilk kuşakları,

New Orleans, 1907,

Cazın zengin adamları

Vieux Carré ve şehrin dışındaki

batakhanelere çektiği zamanlar.

Simsiyahtı ve mutluydu.

karşısına çıkana kadar Louie adında uzun boylu sarı siyah bir zenci,

güzelliğinin hiç farkında değildi. (2005: 11)

Bu dizelerde şair, siyah kadının beden algısını da vurgulamaktadır. Saloy'un büyükannesi gençlik yıllarında bir gün karşısına çıkan uzun boylu "sarı siyah bir zenci” ("yellow nigger") adam ona ne kadar alımlı olduğunu söyleyene kadar, ırksal güzelliğinin farkında olmayacaktır. Bu kendilik ve beden algısını tetikleyen iltifatın "sarı siyah bir zenci" adam tarafından ifade edilmesi önemli bir detaydır. Bu bağlamda, Güney Louisiana’nın Kreole kimlik yapısının diğer Güney eyaletlerinden farklı bir irk konumunu ortaya koyduğunu görmekteyiz. Beyaz ve siyah ırkın melezleşmesine olanak sağlamış olan Fransız ve İspanyol sömürge kültürü, bu birleşmeden ortaya çımış olan yeni melez ırk ile üçüncü bir kategorinin doğmasına sebep olmuştur. Çoğunlukla üst düzey bürokrat ya da toprak sahibi olan bazı Beyaz Kreole babalar melez çocuklarına eğitim ve ekonomik güç sağlamıştır. Çoğu melez nüfus, eğitim ve ekonomik güçten yoksun bırakılmış olsa da sahip oldukları en önemli imtiyaz kölelikten muaf tutulmuş olmalarıdır. Bu konum onlara, diğer siyah ırk nüfusa kıyasla daha üstün bir statü vermiştir. $\mathrm{Bu}$ dizelerdeki söz konusu "sarı siyah zenci" adamın köle olmayan özgür siyahî ırktan olduğu düşünüldüğünde, büyükannenin duymuş olduğu iltifatın ne denli gururunu okşadığı anlaşılmaktadır. Kendisi gibi simsiyah ("jet-black") olmayan birisinden duyduğu bu iltifat, kadının özne konumunu, "ne olmadığını" vurgulayan siyah-beyaz karşılıklı zıtlığının baskısından çekip almıştır.

\section{Sonuç}

Sonuç olarak, Güney Louisiana'da ırk ve etnisite bağlamında mevcut olan kimlik algısı bölgenin sömürgecilik tarihinde gelişmiş belli kültürel unsurlarla çözümlenebilmektedir. Bu yönüyle Güney Louisiana diğer Amerikan Güneyi bölgelerinden farklı olarak kendi yerel kimlik yapısı bağlamında değerlendirilmelidir. Yüzyllar süren sömürge tarihinde birbiriyle iç içe geçmiş Afrika, Karayip, Latin dilleri, inanışları, kimlik tanımları, Güney Louisiana’nın kültürel dokusunu çok sesli ve çoğul bir yapı olarak ortaya koymuştur. Çok-kültürlü yapısına rağmen günümüz Güney Louisiana bölgesinde irk ve etnisite halen önemli bir toplumsal olgudur. Bu yönüyle ABD’nin diğer Güney eyaletlerinden farklı olmamakla birlikte, bu acının tarihine ve sarılmamış yaralarına rağmen kendine özgü bu kültürü ile Güney Louisiana benzersiz bir bölgedir. Güney Louisiana bölgesi, tarihi dokusu, yerel kimlik algısı, gelenekleri ve inanışları bağlamında günümüz küresel kültürün ulus-üstücü bir düzleme çekmiş olduğu çok-kültürlülük deneyimi içinde yerel kalabilmeyi başarabilmiş özgün bir kültüre sahiptir. Bölgenin 1803’te ABD topraklarına dâhil edilmesiyle Fransız ve İspanyol sömürgeciliğinin sona erdiği yeni bir dönem başlamıştır. Fransız ve İspanyol sömürge tarihinden ABD tarihine bölgenin geçirmiş olduğu 
kültürel dönemler, Güney Louisiana için kendine özgü bir yerel kimlik ve kültür algısına tutunma ihtiyacını gerekli kılmıştır. Bu yeni dönemin getirdiği yeni siyasi ve ekonomik iktidar alanı, bölgenin çok-kültürlü yapısı ile ana akım Amerikan kültürünün üst kimliği olan Anglo-Amerikan kimliği arasında sürekli bir çatışma yaratmıştır. Bu çatışma sadece Güneyli beyaz Avrupa kökenli Kreole nüfus üzerinden değil, bölgede genel bir melez kimlik tanımına dönüşmüş olan çok-kültürlü Kreole nüfus üzerinden de sürmeye devam etmektedir. Böylece, Kreole tanımının ilk ortaya çıktı̆̆ı yüzyllardaki ırksal unsurların günümüzde bölgesel kültürel aidiyet duyarlığına dönüştüğü görülmektedir. Günümüz Güney Louisiana'sında Yerli Amerikalı, Afrika Amerikalı, Kajun, Karayip, Latin hatta Asyalı kimliklerin bir arada çağdaş bir Kreole tanımını benimsedikleri anlaşılmaktadır. Kreole tanımında birleşen çokkültürlü yapının en belirgin kültürel ögelerinden birisi Katoliklik ve Afrika-Karayip kökenli inanışlarla bütünleşmiş olan kültürel Katolikliktir. Bu dini kimliğin Anglo-Protestan Amerikan üst kimliğine alternatif bir özerk kimlik ortaya koyduğu gözlemlenmektedir. Bu bağlamda, kültürel inanışların bir araya getirdiği ırksal ve etnik ayrımlar yerel kimlik algısında çözülerek melezlikle bütün bir yapıya dönüşmüştür. Günümüz çok-kültürcü kimlik ve temsil kuramlarının önerdiği kültürel diyalog ve ulusüstücü kültürel etkileşimler Güney Louisiana bölgesinin yerel bir kimlik olarak ana akım ABD siyasi erkine karşı direnişinin gerçekleştiği alanlardır. Fransız ve İspanyol sömürgesi olduğu yüzyıllar Güney Louisiana'ya özgün bir kültürel doku bırakmıştır. Fransa ve İspanya için on yedinci ve on sekizinci yüzyıllarda coğrafi ve siyasi olarak stratejik önem taşımış olan Louisiana, ABD’nin kıtasal yayılma süreci olan on dokuzuncu yüzyılda bu yeni doğmuş ulusun iktidar olarak ivme kazanmasında tarihi bir rol oynamıştır. Güney Louisiana, ABD kültürel bölgeleri arasında bu inkâr edilmiş tarihi dokunun yüzyıllardır canlı tutulduğu bir mekândır. Özellikle İç Savaş öncesi ve sonrası Güneyin sergilediği ayrllıkçı siyasi duruş başta olmak üzere, yüzyllardır farklılıklarla bir arada oluşun meydana getirmiş olduğu Kreole / melez kimlik yapısı, yasaların keskin şekilde çizdiği sınıfsal ve ırksal kategorilere rağmen baskın şekilde önem taşıyan gelenekler, inanışlar, yemek ve müzik gibi kültürel etkileşimler, Güney Louisiana'da ABD’nin ulusal üst kimlik baskısına karşı alternatif bir alan açmıştır. Başta İç Savaş'a dayanan bu eski ulusal travmanın belleği olmak üzere, günümüz Güney Louisiana kültürü, sergilemekte olduğu bu kültürel ögeler bağlamında ABD'nin ötekileştirilmiş bölgesel kimlerinden birisidir. Güney Louisiana kültürünü öteki konumunda tutan en önemli kültürel özelliği ağırlıklı olarak sahip olduğu Katolik kimliğidir. Resmi Katolikliğin yanı sıra Güney Louisiana'daki kültürel Katoliklik halen yaşatılmakta olan bir diğer yaygın inanış sistemidir. Voodoo gibi inanışlara da kapı aralamış olan kültürel Katoliklik, resmi dini otoritelerce tanınmıyor olsa da, kültürel pratik olarak Güney Louisiana'nın yaşam koşullarıyla şekillenmiş melez bir inanış unsuru olmuştur. Jewel Parker Rhodes'un Voodoo Dreams adlı romanı (1993) ve Mona Lisa Saloy'un Red Beans and Ricely Yours (2005) adlı şiir kitabı, bu çok kültürlü diyalojinin temsil edildiği çağdaş örneklerdir. Her iki eserde ağırlıklı olarak vurgulanan yerellik algısı, bölgedeki ırk çatışmalarının çözüldüğü önemli bir unsurdur. Bu eserlerden seçilmiş olan insan figürleri, Louisiana'nın mekân olarak algılanış şeklini ve bu özel tarihi dokusuyla özgünleşmiş bir yerellik hissini vurgulamaktadır. Barındırdığı ağır tarihi gerçeklerin travmasına rağmen Güney Louisiana, Louisianalılar için vazgeçilmez bir kimlik aidiyet olgusudur. Sonuç olarak, günümüz küresel kültürün yarattığı yeni mekân ve kimlik algısının yok etmeye çalıştığı yerellik, özgünlük gibi sınır kimlik unsurlarının korunması bağlamında, Güney Louisiana'nın, küresel mekânsızlaşma ve kimliksizleşmeye karşı etkin bir direniş gösterdiği anlaşılmaktadır.

\section{Kaynakça}

Ashcroft, Bill, Gareth Griffiths \& Helen Tiffin. Post-Colonial Studies. The Key Concepts. (Second edition). (2007). Routledge.

Bauer, Ralph \& José Antonio Mazzotti (ed). (2009). Introduction. Creole Subjects in the Colonial Americas Empires, Texts, Identities. The University of North Carolina Press. 
Bauer, Ralph. (2003). The Cultural Geography of Colonial American Literatures. Empire, Travel, Modernity. UK, Cambridge University Press.

Bienvenu, Germain. (2008). "The Beginnings of Louisiana Literature: The French Domination of 16821763." Louisiana Culture From The Colonial Era To Katrina. John Lowe. Louisiana State University Press. (25 - 48)

Coles, Kimberly Anne, Ralph Bauer, Zita Nunes, Carla L. Peterson (eds.) (2014). The Cultural Politics of Blood, 150o-19oo. Palgrave Macmillan.

Evans, Freddi Williams. (2011). Congo Square African Roots in New Orleans. University of Lafayette Press.

Gaudet, Marcia. "Cultural Catholicism in Cajun-Creole Louisiana" (Folk Life in Louisiana) http://www.louisianafolklife.org/LT/Articles_Essays/CulturalCatholicism.html adlı web sitesinden alınmıştır. 06. 10. 2019.

Kristeva, Julia. (2014). Korkunun Güçleri İğrençlik Üzerine Deneme. Nilgün Tural(çev.). Ayrıntı.

Ostendorf, Berndt. (2008). "Creole Cultures and the Process of Creolization: With Special Attention to Louisiana.” Louisiana Culture From The Colonial Era To Katrina. John Lowe. Louisiana State University Press. (103 - 134)

Rhodes, Jewel Parker. (1993). Voodoo Dreams. Picador.

Ritter, Alexander. "Louisiana - the New Egypt: Charles Sealsfield's Report from the 1820s." Louisiana Culture From The Colonial Era To Katrina. John Lowe. Louisiana State University Press, 2008. $(49-74)$

Saloy, Mona Lisa. (2005). Red Beans and Ricely Yours. Truman State University Press.

Tallant, Robert. (2012). Voodoo in New Orleans. Pelican Publishing Company. 